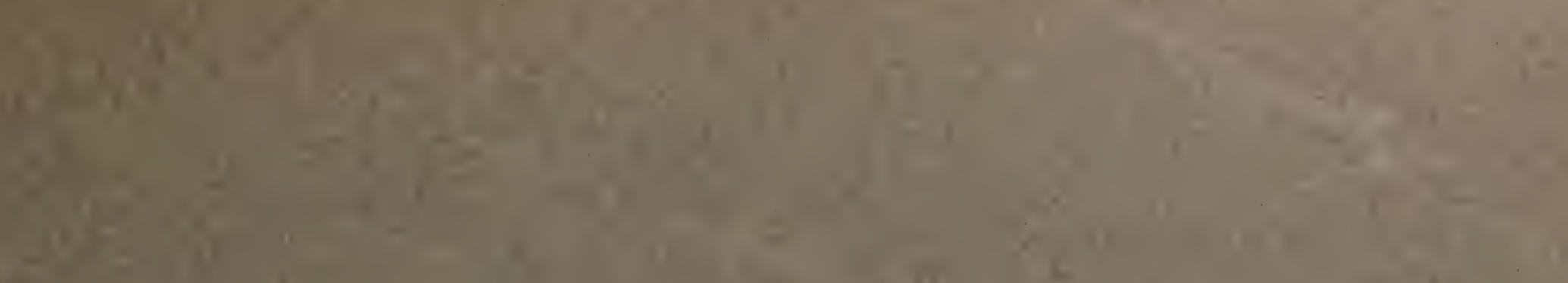

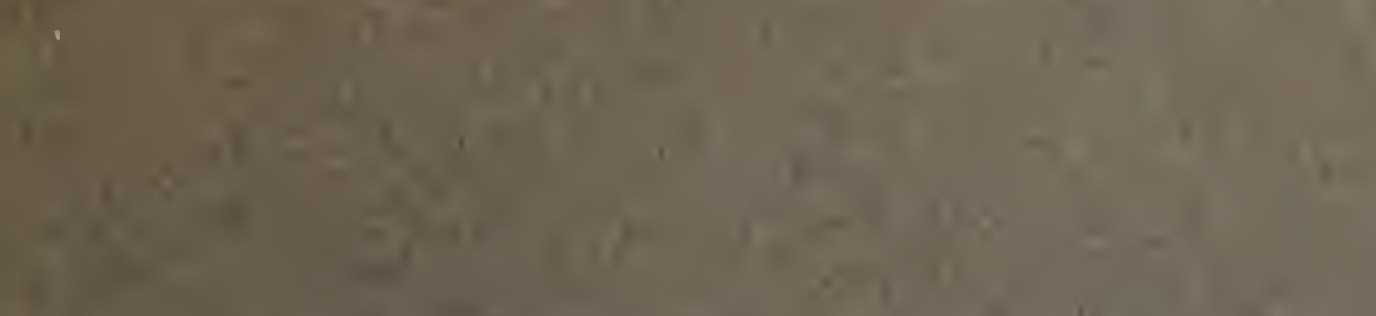




\section{HARVARD UNIVERSITY.}

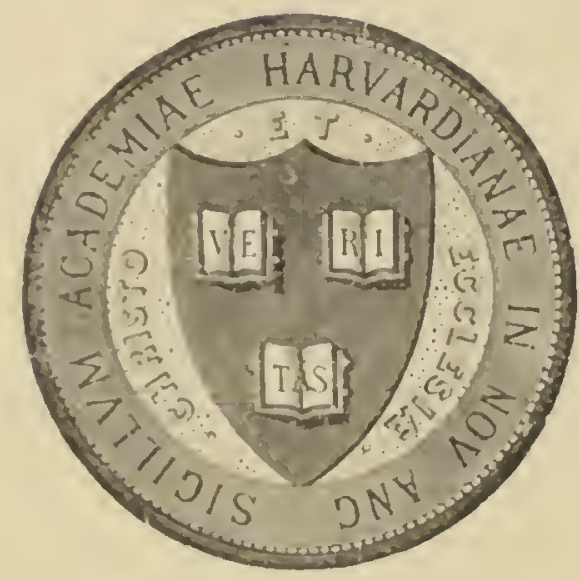

I, I I I I A IR I

OF TH:

MUSEUM OF COMPARATIVE ZOÖLOGY.

$$
\text { Exchange }
$$

December 1\% 1919 


\section{FARMERS BUILLE'TIN 1069}

UNITED STATES DEPARTMENT OF AGRICUITURE

52,988

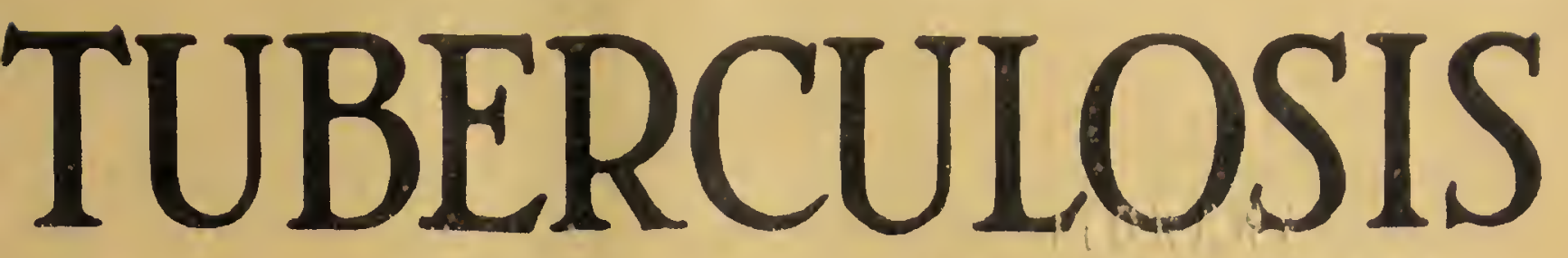

IN LIVE STOCK

Detection,Contiol,

and Eradication

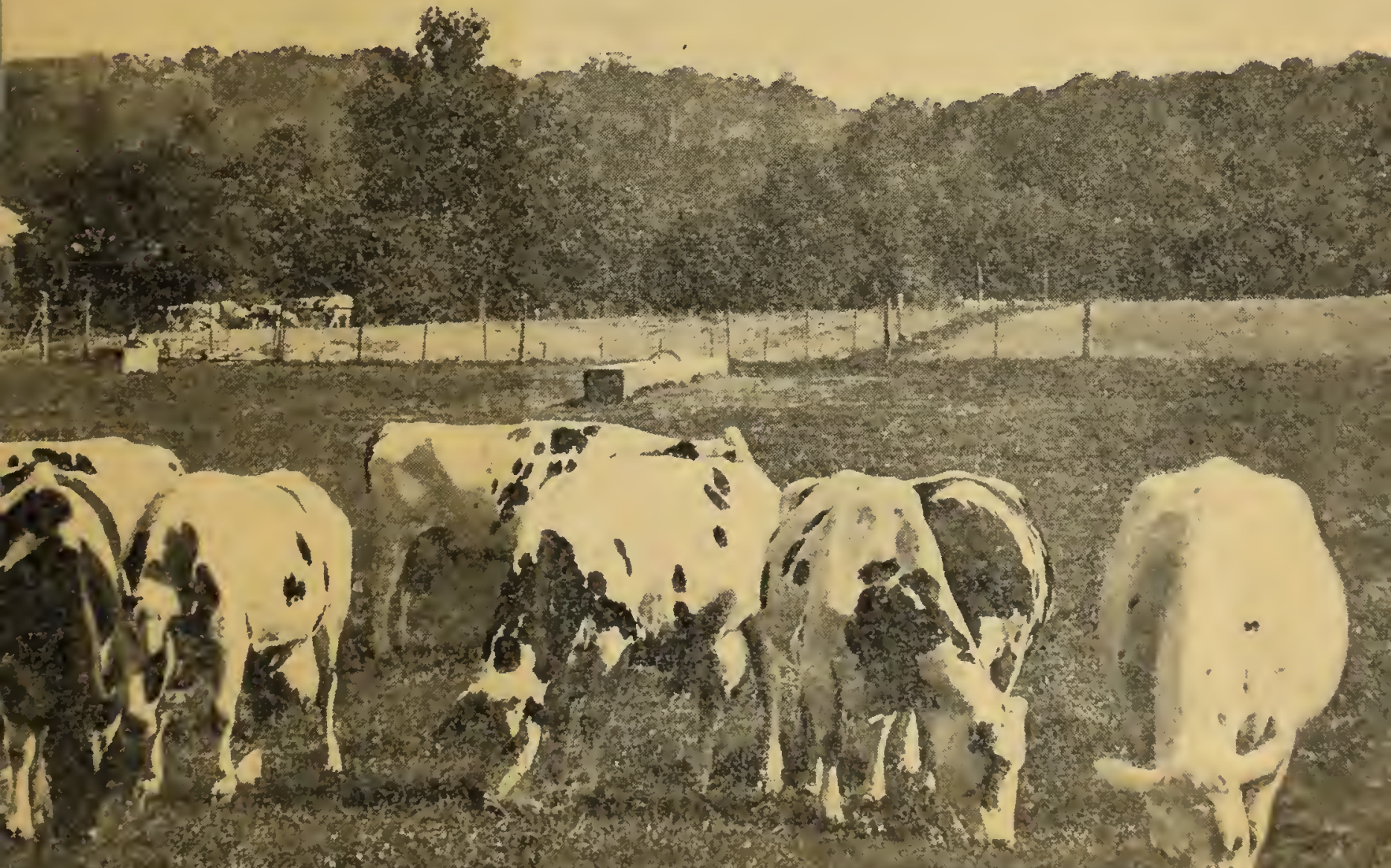

HHE FIRST FERD IN MIE UNITED STATES OEEICIALD ACCREDITED AS EREE FROM TUBERCUILOSIS. 


\section{HOW TUBERCIULOSIS SPREADS FROM $\Lambda$ DISEASED HERD TO A HEALTHY ONE.}

TUBERCULOSIS may be introduced into a healthy herd by any
of the following means:

By the addition of an animal that is affected with the discase; therefore animals should be purchased only from lrerds known to be free from tuberculosis, or from herds under supervision for the eradication of the disease.

By feeding calves with milk or other lairy products from tubereulous cows; this frequently occurs where the owner purchases mixed skim milk from the creanery, and feeds it to his calves without first making it safe by boiling or pasteurization.

By showing cattle at fairs and exhibitions; reports have indicated that mumerous herds have becone infected through mingling with infected cattle at shows or by occupying infected premises.

The shipment of animals in cars which lave recently carried discaserl cattle and which have not been disinfected properly.

Commmity pastures; pastures in which tuberculous cattle are allowed to graze are a source of danger.

In most cases the outward appearance of the animal bears no relation to the degree of infection. The disease frequently develops so slowly that in some cases it may be momths or even longer before any symptoms are shown; therefore be on the safe side and have your lierd tested.

Contribution from the Burean of Animal Industry JOHN H. MOHLlen, Chief

Washington, D. C. 


\title{
TUBERCULOSIS IN LIVE STOCK.
}

\author{
DETECTION, CONTROL, AND ERADICATION.
}

Jomn A. Krennan, Chief of Tuberculosis Fradiculion Division, and Alexaxners Wrant, Assistant chief.

\section{CONTENTS.}

\begin{tabular}{|c|c|c|c|}
\hline \multicolumn{3}{|c|}{ Page. } & I'age. \\
\hline Present knowledge of tubereulosis.... & 3 & Methods of eradication ................. & 18 \\
\hline Early eradication is most cconomical. . & 3 & Accredited-herd or honor-roll plan & 19 \\
\hline Tuberculosis a deceptive disease...... & 5 & Eradication from areas............... & 22 \\
\hline Prevalence of tuberculosis............. & 5 & Eradication from swinc............. & 25 \\
\hline Losses of meat food products...... & 8 & Measures of prevention $\ldots \ldots \ldots \ldots \ldots$ & $2 j$ \\
\hline Cause of tuberculosis....... & 9 & Disposal of reactors....... & 28 \\
\hline Symptoms of tubereulosis. . & 12 & Retesting $\ldots \ldots \ldots \ldots \ldots \ldots \ldots$ & 29 \\
\hline Methods of diagnosis....... & 14 & Marking animals for identiflcation... & 29 \\
\hline The tuberculin test.... & 15 & Appraisement and indemnity........ & 30 \\
\hline Ost-mortem appearances. & 18 & & \\
\hline
\end{tabular}

\section{PRESENT KNOWLEDGE OF TUBERCULOSIS.}

DROBABLY no disease affecting either the human race or live I stock is bettel known or has been the object of so much study as tuberculosis. Present knowledge of the disease is derived from many sources, including the work of eminent sciontists who discovered its cause, and studies of the numerous ways in which it is spread, of the manner by which man and animals contract it, and the effects it produces.

The tuberculin test - the means of detecting tuberculosis-was devised in $18 S 2$ by the eminent scientist, Dr. Robert Koch. Thus the test has been known for more than a third of a century. The facts regarding it and other information presented in this bulletin are based upon long experience and results verified many times. The meihods recommended to be used in the eradication of tuberculosis have been tried upon large numbers of herds and found to be effectual and practicable.

\section{EARLY ERADICATION IS MOST ECONOMICAL.}

Live-stock owners are earnestly requested not to wait until the States and Federal Government come into their localities to eradicate tuberculosis. It would not be possible indeed, at this stage to undertake to eradicate tuberculosis from the live stock of the United States solely through organized official forces established by the respective States and the Federal Government. The area over which tuberculosis has spread is too vast, the herds too numerous, and 
funds are insufficient for conducting the work on so extensive a plan eren though trained reterinarians were arailable in sufficient number's to do the work. Every live-stock owner should be a party to this campaign which has been inaugurated to eradicate tuberculosis. In almost every locality of the United States are reterinarians capable of rendering valuable serrices to live-stock owners in this great work, and the cost of eradicating is greatly reduced by combating the disease in its early stages. Yet eren in badly affected herds eradication can be undertaken with success. There are records of many herds, in which three-fourths of the animals

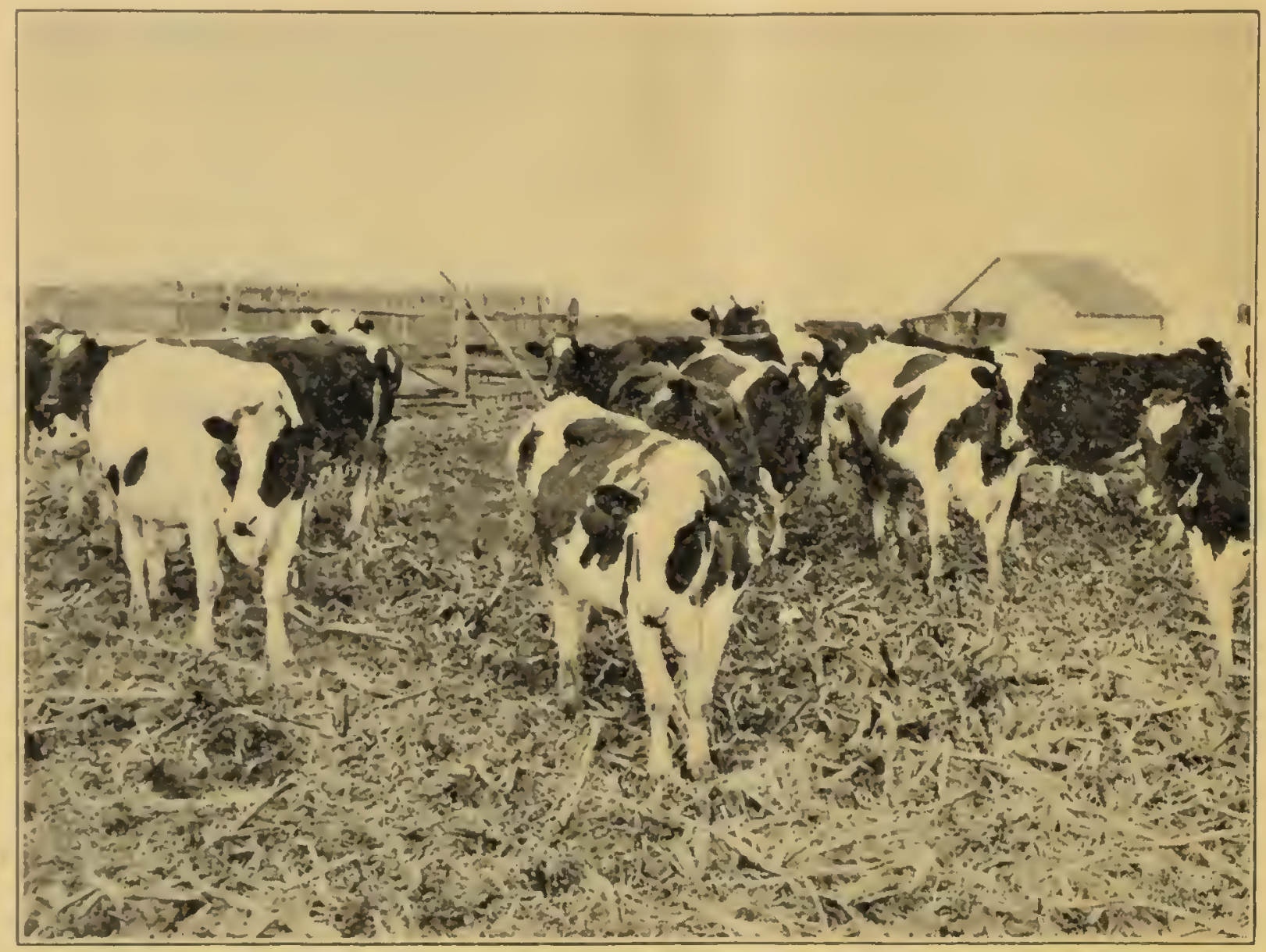

Fig. 1.-Portion of a herd of $4 j$ cattle showing no external symptoms of tuberculosis. Upon application of the tuberculin test, 37 , or 82 per cent, of the animals were found to be tuberculous. The germs of the disease may live for months in manuro or litter.

were affected with tubereulosis, which eventually were freed from it and afterwards maintained in a healthy condition.

The cxtirpation of tuberculosis from live stock is important not only from an economic standpoint, but also because a considerable percentage of tuberculosis in the human family, especially among children, is positirely due to the consumption of infected milk or other dairy products from tuberculous cows. It is eminently proper for the respective State governments to expend funds for the maintenance of tuberculosis sanitariums for the care of persons aflicted with that disease, and likewise it is extremely important to use rigorous measures to check the marketing of germ-laden milk. While it is true that proper pasteurization of milk destroys the living organisms 
of tuberculosis, a large part of the milk consumed daily is not pasteurized, and some of the milk so treated is not always mado entirely safe.

\section{TUBERCULOSIS A DECEPTIVE DISEASE.}

If tuberculosis were similar to foot-and-mouth disease in cattle, swine, and sheep, which causes rather spoctacular symptoms, it would arouse immediate alarm among the live-stock owners, who would insist upon its immediate eradication; but because it is gencrally slow in dereloping and its symptoms commonly are not easily recognized from the general outward appearance of the animals, many people believe that it does comparatively little damage among live stock. Contrary to such opinions, however, the loss from tuberculosis is one of the heariest taxes imposed upon our live-stock industry, amounting, probably, to at least $\$ 40,000,000$ a year in the United States.

\section{PREVALENCE OF TUBERCULOSIS.}

In every State and Territory in the Union there is some tuberculosis among cattle and swine, though the degree varies considerably. In some States it probably exists quite extensively, the percentage rarying from 5 to 30 per cent of the cattle population, while in certain others investigations indicate that less than 1 per cent of the total of beef and dairy cattle are tuberculous.

Tuberculosis is known to exist also quite extensively among cattle and swine in all the European countries; in fact, no part of the world is known to be free from it absolutely. There are, however, some restricted regions where its presence is not known, or it exists to but a very moderate degree.

Until cattle from the eastern part of the United States were introduced into the Middle Western, Western, and Southern States, tuberculosis among live stock in those regions was unknown so far as we know. The disease at that time was confined to the herds east of the Allegheny Mountains. It was known then that a considerable percentage of herds in those States were affected, but livestock owners were not inclined to consider tuberculosis as of rery great economic importance or dangerous to human health. Therefore very little progress was made in its eradication. As the Central and Western States became settled and cattle were mored westward the disease spread much more rapidly than is generally realized. The spreading in those areas is due, of course, to the fact that the livestock industry occupies a more important part in agriculture than in the Eastern States. Cattle are traded in more extensively and are continually being shipped and trailed from State to State and from farm to farm. 
In some localities in the West, where dairying has developed cxtensircly, it is now known that carload lots of cows purchased in other States have contained 50 per eent or more of tuberculous animals. Some herds of beef cattle in our western country have become contaminated with the disease by placing among them tuberculous pure-bred bulls and cows that eame from discased herds clscwhere. The importance of controlling tuberculosis and presenting its spread by the interstate morement of discased animals was not so well recognized during the times of pionecr development as it is to-day. Consequently in the absenec of reculations and inspection, discased animals mored from one State to another. The shipment of cattle from Eastern and Northern States to the South, with the exeption of dairy herds near the larerer cities, did not commence until progress had been made in the eradication of the cattle tick. Therefore there is probably less tubcreulosis among the herds of the Southern States than in any other part of the Nation. This farorable condition should be taken adrantage of, for in all probability the live-stock industry will reach a high derelopment in that area in future years. It is especially important that the herds of the Southern States be protected by permiting only tuberculosis-free animals to enter.

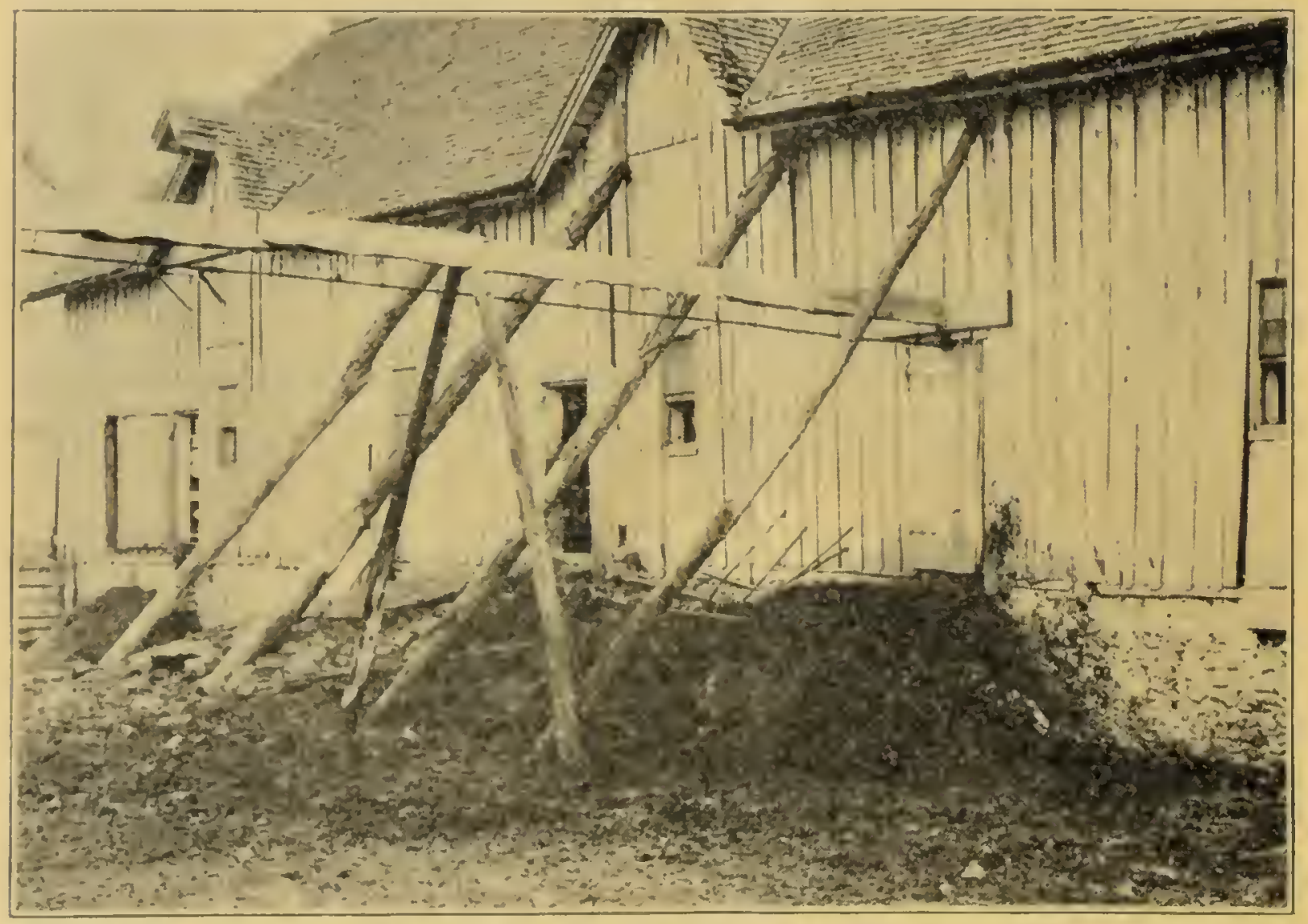

Fig. 2.- In insanitary harn. Nearly all the cows kept in it were tuherculous. The stone foundation wall retains about 2 feet of liquid manure which contains millions of tubercle germs. I'remises of this ch brater can not he kept sanitary. 


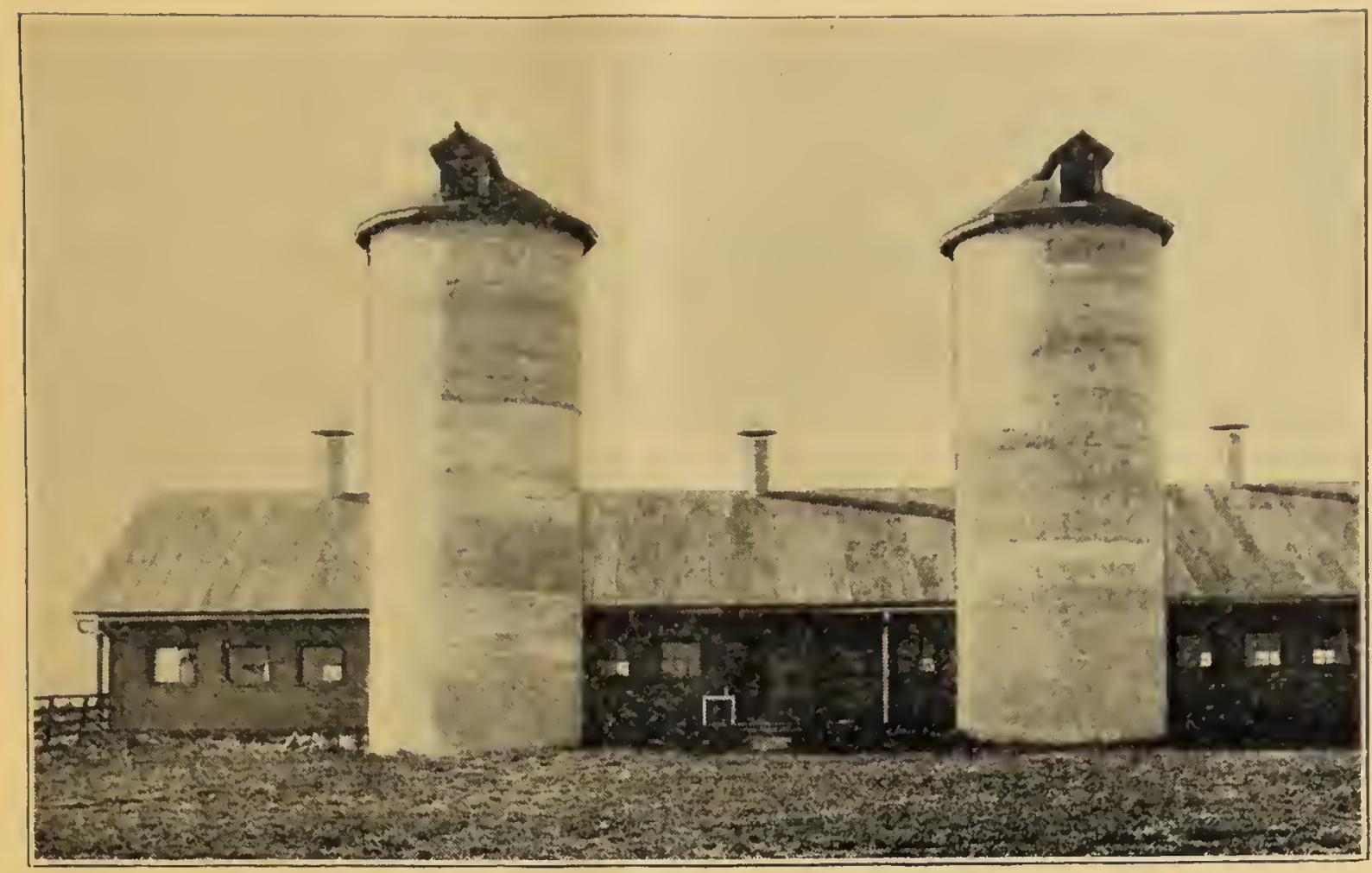

FIG. 3.- $\Lambda$ modern sanitary barn. Note ventilators and liberal window space.

HOW THE DISEASE SPREADS IN A HERD.

The tuberculous cow is the greatest source of danger to healthy cattle. Any reacting cattle not promptly removed from the herd constitute a source of constant infection.

Tuberculous cattle, sooner or later, begin to give off the germs of the disease. These germs escape by the mouth, nose, and bowels, in the milk, and other discharges. The discharged germs are carried in the air for a time until they fall to the ground.

Animals in adjoining stalls may take in the germs in the feed they eat and thus contract the disease. Continuous water troughs in barns containing diseased cattle are a source of danger. Drinking holes containing material from infected animals are likewise dangerous.

Failure to clean and disinfect the premises occupied by the diseased cattle constitutes another source of danger. Infected milking tubes and the practice of feeding calves with raw milk from tuberculous cows are other means by which tuberculosis spreads in a herd. 


\section{LOSSES OF MEAT FOOD PRODUCTS.}

Records kept by the Meat Inspection Division of the bureau show the great financial loss caused by tuberculosis every yenr. They also indicate how widespread tuberculosis in cattle and swine is in the United States, as the establishments in which the diseased animals were slaughtered are in all parts of the country. More than that, only about 65 per cent of the cattle and swine, it is estimated, are slaughtered each year in establishments under Federal supervision, so that about 35 per cent of these classes of animals slaughtered each year in the United States do not appear in these records. It is known also that the percentage of tuberculosis is greater in the uninspected animals. In view of these points the losses shown in the following table are believed to be scarcely one-lialf of the total loss throughout the country.

When animals are "retained" by the Federal inspectors on account of tuberculosis it means that some evidence of the disease is discorered and the carcass is placed aside for further examination. If the disease is found to be so slight as to render the undiseased portion of the carcass fit for food, the diseased area is removed and the remainder is passed. It will be noted that such is the case in most carcasses retaned, but some loss occur's for the reason that the diseased portions found unfit for food would have a considerable value if healthy.

In the animals that are retained and when the disease is not extensive enough to cause condemmation of the entire carcass, the disease is in most cases in the early stages. Had the animals been allowed to live for possibly only a short time longrer, the disease would have progressed until all the carcass would have to be considered diseased. In others the lesion of disease has become surrounded by tissue that "locks it up" and prevents it from spreading to other parts of the body. Such a condition, however, is liable to changre at any time during the animal's life and allow the disease to enter other parts of the body, and also to be carried out of the body and endanger healthy cattle and swine.

HOW TO PROCEED TO MAKE CERTAIN THAT CATTLE AND SWINE ARE FREE FROM TUBERCULOSIS.

Have a competent veterinarian apply the tuberculin test. Remove all reactors promptly, and disinfect the premises immediately after the removal of the reacting cattle.

Do not feed any infected dairy products to swine or young cattle.

Retest the herd with tuberculin once a year. 
On the farms from which these animals came, some of the remaining cattle and swine are probably affected with tuberculosis, or will be if allowed to remain there for a sufficient length of time. Knowing this danger, State and Federal officials, when the identity of the animals can be established, trace back as many of the shipments of diseased animals as possible, and through the cooperation of the owner try to exterminate the disease from that farm.

TABLE 1.-Number of catlle and swine slaughtered, and those retained and condemred on account of tuberculosis at estublishmen's where Fiderul meat inspetion is maintuincd.

\begin{tabular}{|c|c|c|c|c|c|c|}
\hline \multicolumn{4}{|c|}{ Cattlo. } & \multicolumn{3}{|c|}{ Swine. } \\
\hline Fiscal year. & Slaughtered. & Retained. & Condemned. & Slaughtered. & Retained: & Condemned. \\
\hline 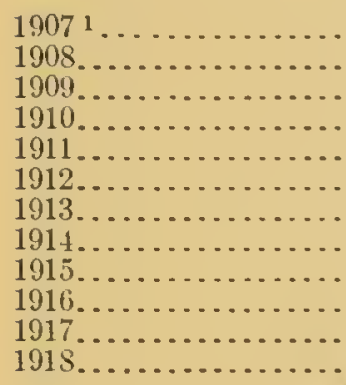 & $\begin{array}{r}5,867,642 \\
7,116,275 \\
7,325,337 \\
7,962,199 \\
7,781,030 \\
7,532,005 \\
7,155,816 \\
6,724,117 \\
6,964,402 \\
7,404,288 \\
9,299,489 \\
10,938,287\end{array}$ & $\begin{array}{r}24,876 \\
68,395 \\
100,650 \\
123,501 \\
133,551 \\
160,122 \\
152,560 \\
143,699 \\
158,239 \\
190,991 \\
218,928 \\
222,787\end{array}$ & $\begin{array}{l}17,117 \\
24,371 \\
24,525 \\
27,638 \\
27,186 \\
35,273 \\
33,091 \\
29,738 \\
32,644 \\
37,085 \\
46,351 \\
40,692\end{array}$ & $\begin{array}{l}26,189,026 \\
35,113,077 \\
35,427,931 \\
27,656,021 \\
29,916,363 \\
34,966,378 \\
32,287,538 \\
33,289,705 \\
36,247,958 \\
40,482,799 \\
40,210,847 \\
35,449,247\end{array}$ & $\begin{array}{r}362,445 \\
719,279 \\
860,425 \\
792,176 \\
1,117,789 \\
1,643,100 \\
1,809,751 \\
2,201,005 \\
2,774,835 \\
3,687817 \\
3,970,168 \\
2,494,587\end{array}$ & $\begin{array}{l}48,544 \\
77,554 \\
45,113 \\
28,880 \\
31,517 \\
42,267 \\
47,632 \\
48,252 \\
66,0: 3 \\
74,109 \\
76,807 \\
59,740\end{array}$ \\
\hline
\end{tabular}

1 Covers 9 months from October 1, 1906, to June 30, 1907.

\section{CAUSE OF TUBERCULOSIS.}

The direct and primary cause of tuberculosis is a rod-shaped germ which can be seen only with the aid of a microscope of high magnifying power. The presence of this germ in the bodies of human beings or live stock is absolutely necessary to produce the disease. The germs of tuberculosis may also be grown artificially in proper material at a temperature of about $98^{\circ} \mathrm{F}$.

Outside the bodies of animals the organism is not capable of reproducing itself. When exposed to the direct rays of the sun it dies quickly - a fact to be noted in the disinfection of pastures, paddocks, and barn lots. The organism may live for' months, however, when it is protected by dry manure and other materials which form a crust over it and prevent its destruction by the sun's rays. It is of extreme importance, therefore, to clean and disinfect thoroughly all barns, stalls, and other inclosures which contained tuberculous animals before healthy ones are again placed in them.

While it is necessary for the germs of tuberculosis to be introduced into the body of the animal before the disoase can be produced, there are many conditions or accessory causcs which make animals fall victims to tuberculosis.

Animals which are fed on nomnutritious feeds, as well as those that have too little feed, become weakened constitutionally and lose $133960^{\circ}-19-$ Bull. $1069-2$ 
the power to resist the invasion of the organisms. Stabling animals in dark, poorly rentilated, and dirty barns helps to spread tuberculosis among the stock whenerer the germs are present. Introducing a tuberculous animal is almost sure to give the discase to healthy animals in a short time. If the healthy animals drink water from the same trough or bucket the tuberculous animal uses, and if that animal is coughing up tuberculous sputum, all the animals are in serious danger of infection. Any condition that produces constant strain upon the systems of animals, such as the continued foreed lactation periods of dairy cows, renders them fit subjects for the derelopment of tuberculosis.

\section{HOW CATTLE BECOME INFECTED WITH TUBERCULOSIS.}

The tuberculous cow is the greatest souree of danger to healthy cattle, and inasmuch as it can not be determined just when that animal becomes a "spreader" of the germs, unless daily microscopic tests are made of the discharges from the body, and the milk is also cxamined microseopicaly, it is unsafe to keep it with healthy cattle. No cattle from outside sources should be introduced into a healthy herd until they hare been tuberculin tested and found free from the disease. Unquestionably more healthy cattle acquire tubereulosis by coming into contact with affected animals than in any other

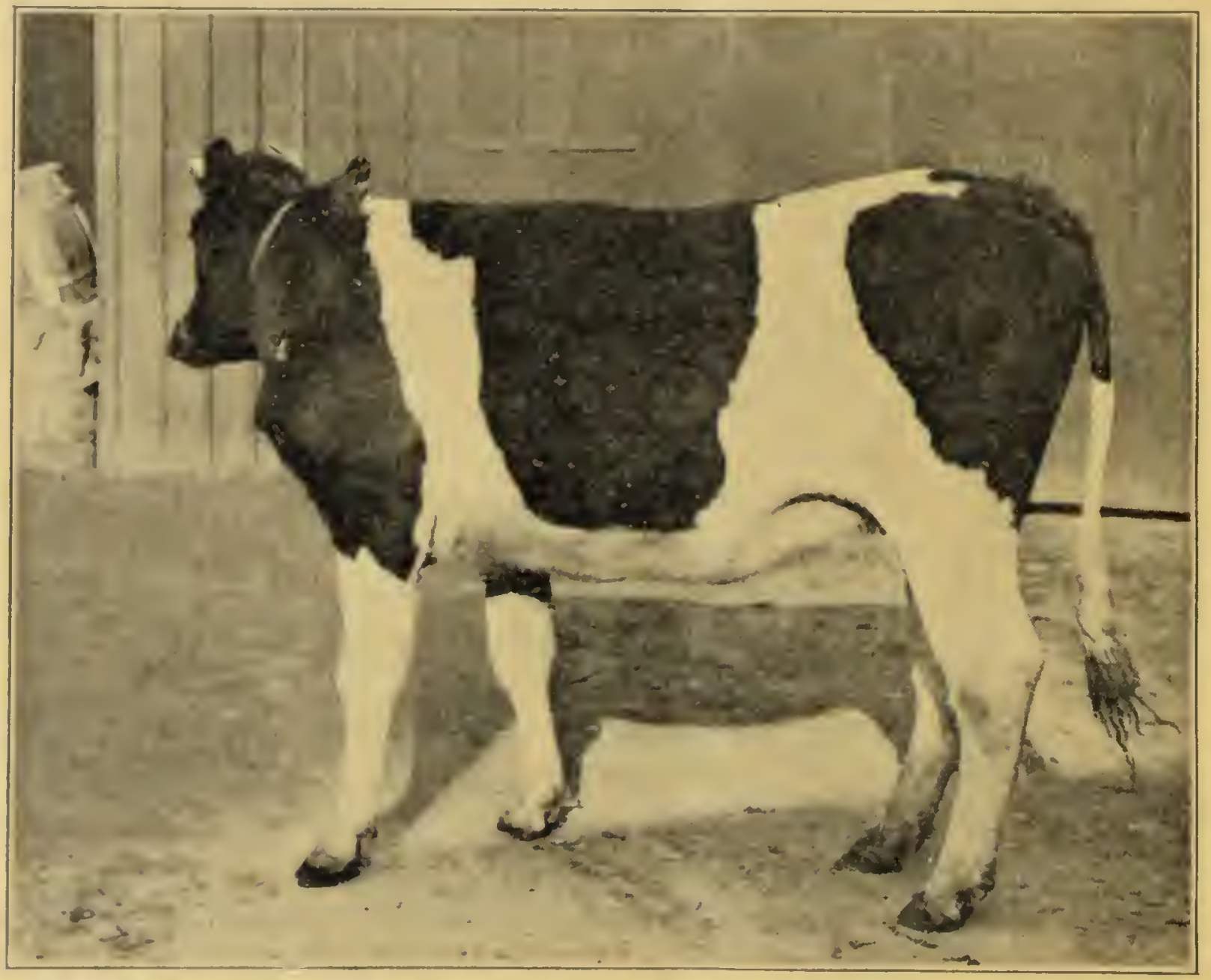

Fir. 4.-1 tuberculous heifer. The gland at tho shoulder was diseased and discliarging tuberculous pus. 
way. It has been observed frequently that cattle which stand on either side of or face tuberculous animals in barns are the first to contract the disease.

The continuous water trough in barns is also accountable to a very large extent for spreading the disease. Cattle may become infected by picking over manure infected with the germs of tubereulosis. Hay, straw, or any other feed contaminated with the germs may give the disease to animals that consume such material.

Water holes and creeks into which infected milk or the washings from infected milk cans have been dumped may also be a sourece of the infection. 'The teat siphon or milling tube, in a number of instances, has been the medium by which the disease has been conveyed from one animal to another. Calves contract tubereulosis by nursing, even for a short time, cows whose udders are affected. Calves also become infected frequently by drinking milk from diseased cattle isolated from the main herd. 'To be safe for feed, milk from such cows should first be heated to a temperature of $145^{\circ} \mathrm{F}$. and held there for at least 30 minutes, but as this method requires considerable attention to assure proper heating, boiling for a few minutes is considered a better plan.

\section{HOW SWINE MAY BECOME INFECTED.}

The tuberculous cow is not only a menace to other cattle but is also the commonest source of infection to swine. In some parts of the country, especially where there are whole-milk creameries and skimming stations, feeding mixed skim milk to swine is a common practice. In that way the skim milk from one farm may be fed to hogs on another. Thus it is possible that milk from a few tuberculous cows may set up the infection among swine on many farms.

Milk is a good medium for the development of the tubercle bacilli, and swine seem to be extremely susceptible to tuberculosis. Numerous instances are on record, also, in which the whole milk is separated on the farm, the cream shipped, and the skim milk fed to swine. Consequently one tuberculous animal that is passing the germs in the milk secretions may give the disease to any or all of the animals to which any of the milk is fed. Investigations made by the Bureau of Animal Industry show that in practically erery instance where tuberculosis exists among cattle, and swine are kept on the same farm, some of the latter are tuberculous. Eradication of tuberculosis from cattle, it is believed, will greatly reduce its prevalence among swine.

Another common practice of feeding, especially in the Corn Belt States is to allow hogs to run with cattle in the feed lots or pastures. If the cattle are tuberculous and the feces contain the germs of tuber- 
culosis, in all probability the swine will contract the disease. Swine may contract tubciculosis also by cating parts of the carcasses of infected cattle, swine, or poultry. Other sources of contamination are infected sputum from human beings, and the feeding of uncooked garbage containing the germs of tuberculosis. Tubereulous swine, like discased cattle, may also infect one another.

\section{SYMPTOMS OF TUBERCULOSIS.}

It must be understood that tuberculosis is a discase which of ten gires no indication of its presence by external srmptoms. Tet persons skilled and experienced in dealing with the discase among animals frequently are able to detect certain abnormal conditions

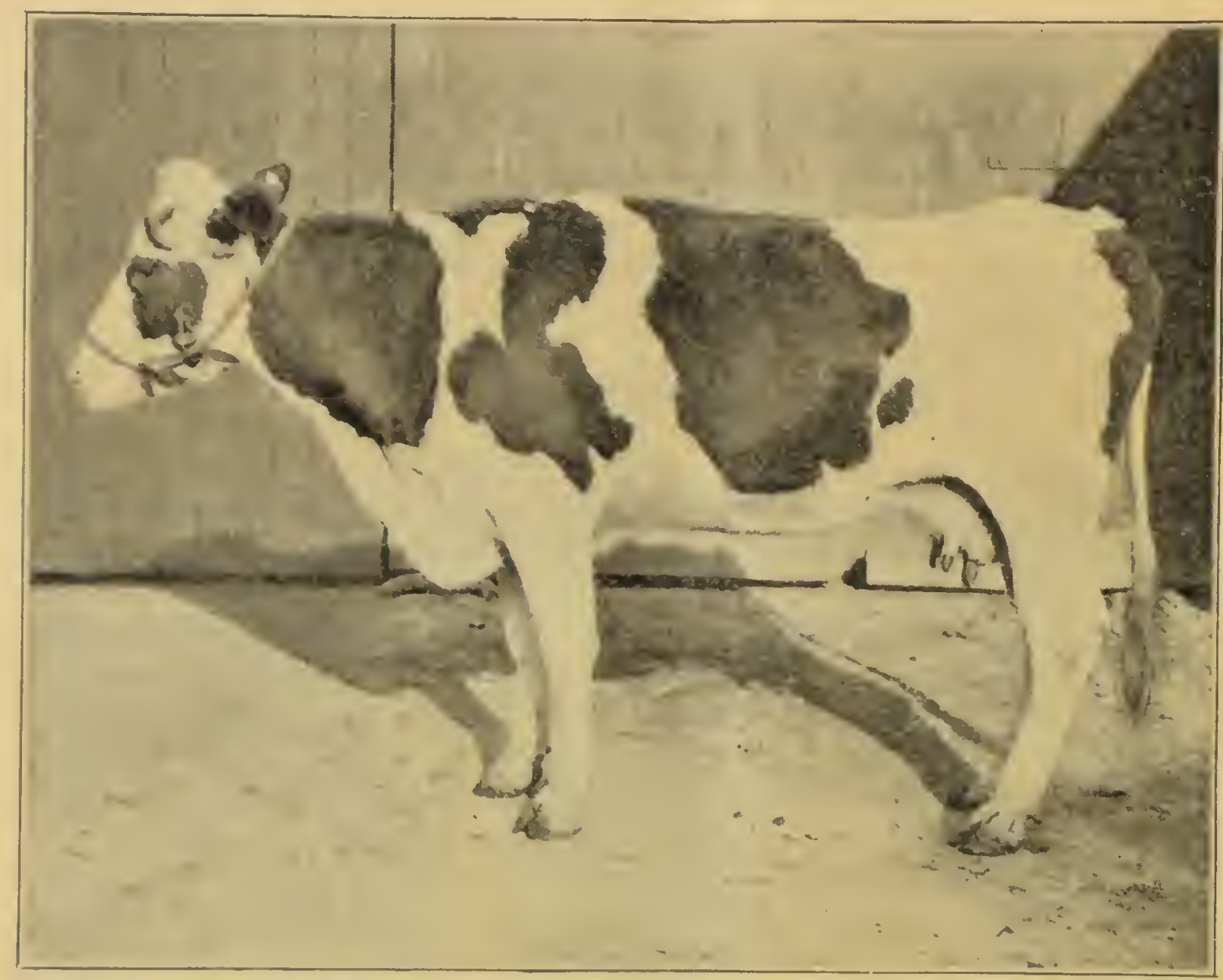

FIG. 5.- I reacting cow that was constantly "blonting." The pressure of greatly enlarged tuberculous glands on the gullet was the cause of the bloating.

which lead them to pronomec the animal as probably affected with tuberculosis. A generally Iun-down condition, accompanicd with a cough, is often considered to be an indication of tuberculosis but is not a conclusire symptom. When tubereulosis is suspected it is always advisable to apply the tuberculin test without delay.

As the discase often involves the lymphatic glands in various parts of the budy, an cxamination of such glands as can be folt in the living animal is sometimes helpful in diagnosing the disease. 'The glands 
of the throat, udder, and point of the shoulder often present an abnormal condition, such as an enlargement or hardening, as shown in figure 4. Animals affected with tuberculosis in adranced stages often show a "staring" coat and a generally unthrifty condition. When the throat glands of an animal are affected, it of ten holds its head in an abnormal position in order to relieve the pressure which causes difficult breathing. Increased respiration is often noted when the lungs or lymphatic glands of the thoracic cavity are affected. When some of the glands of that carity are extensively diseased, the animal of ten develops bloat (fig. 5). Diarrhea is often evident in some cases in which infection has extended to the abdominal cavity. The symptoms mentioned, though typical, must not always be expected when animals are tuberculous; animals that are extensively diseased are often in apparently perfect physical condition.

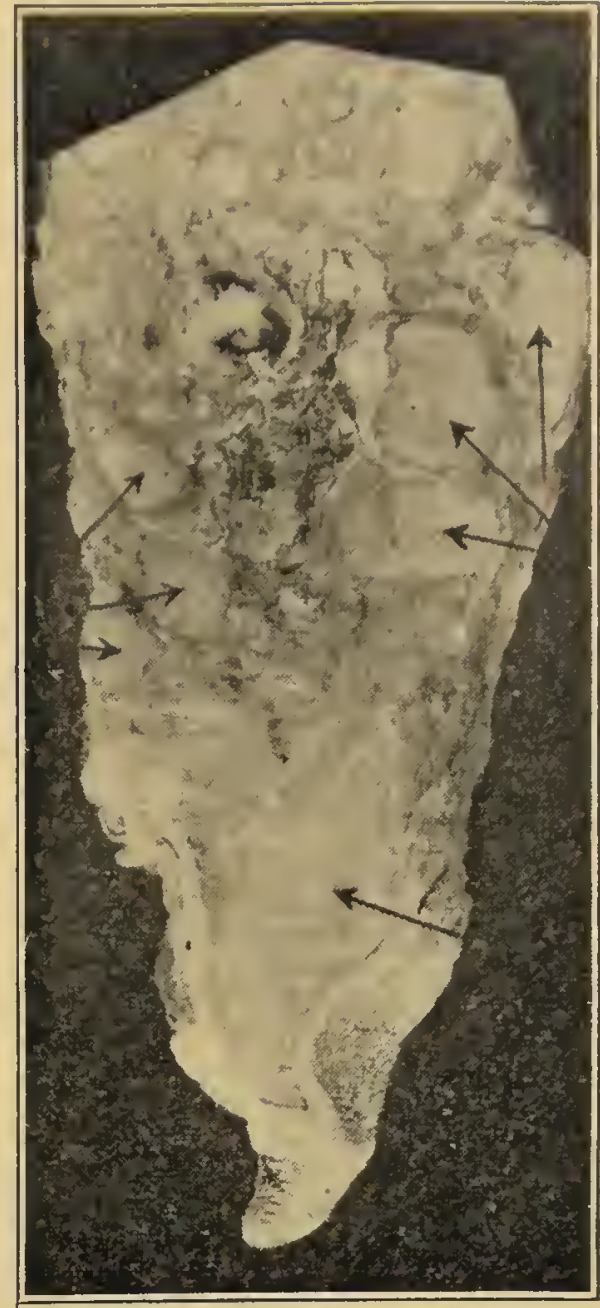

FIG. 6.-Part of a tuberculous udder showing well-developed lesions.

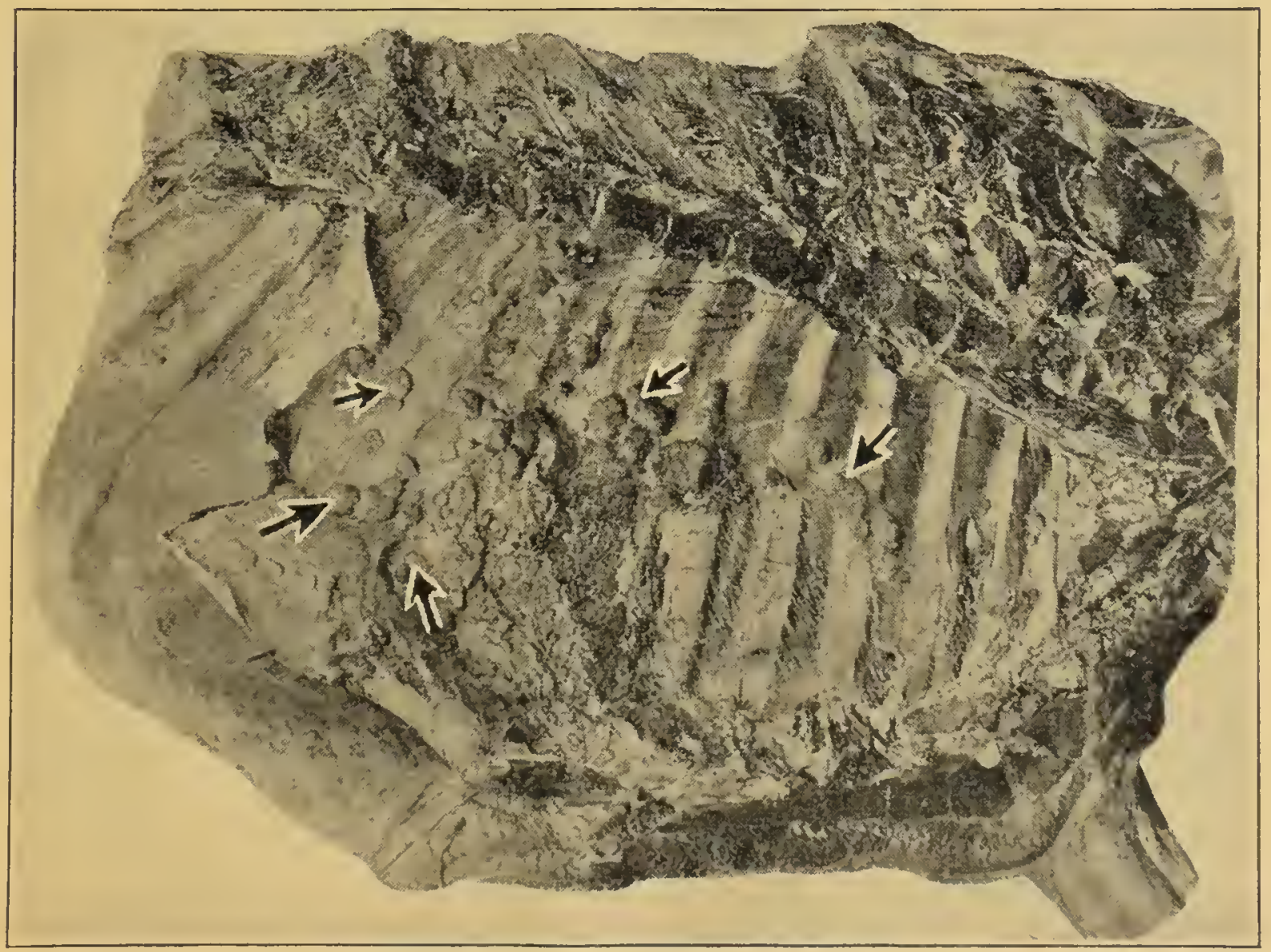

FIG. 7.-Beef carcass showing tuberculous nodules on ribs. 


\section{METHODS OF DIAGNOSIS.}

Microscopic cxaminations of sputum, milk, and bowel discharges of an animal are sometimes made to determine the presence of tubercle bacilli and to diagnose tuberculosis, but after many years of experience the tuberculin test is now considered to be the most practicalle and satisfactory way of discovering the disease in the living animal. The inoculation of gruinea pigs with emulsions made from milk or discharges from the liring animals is sometimes resorted to as a means of diagnosis, but that method of examination is technical and requires special scientific training and equipment. Besicles, cases of tuberculosis may be orerlooked when laboratory methods are used, because tuberculous animals do not always discharge the tubercle bacilli.

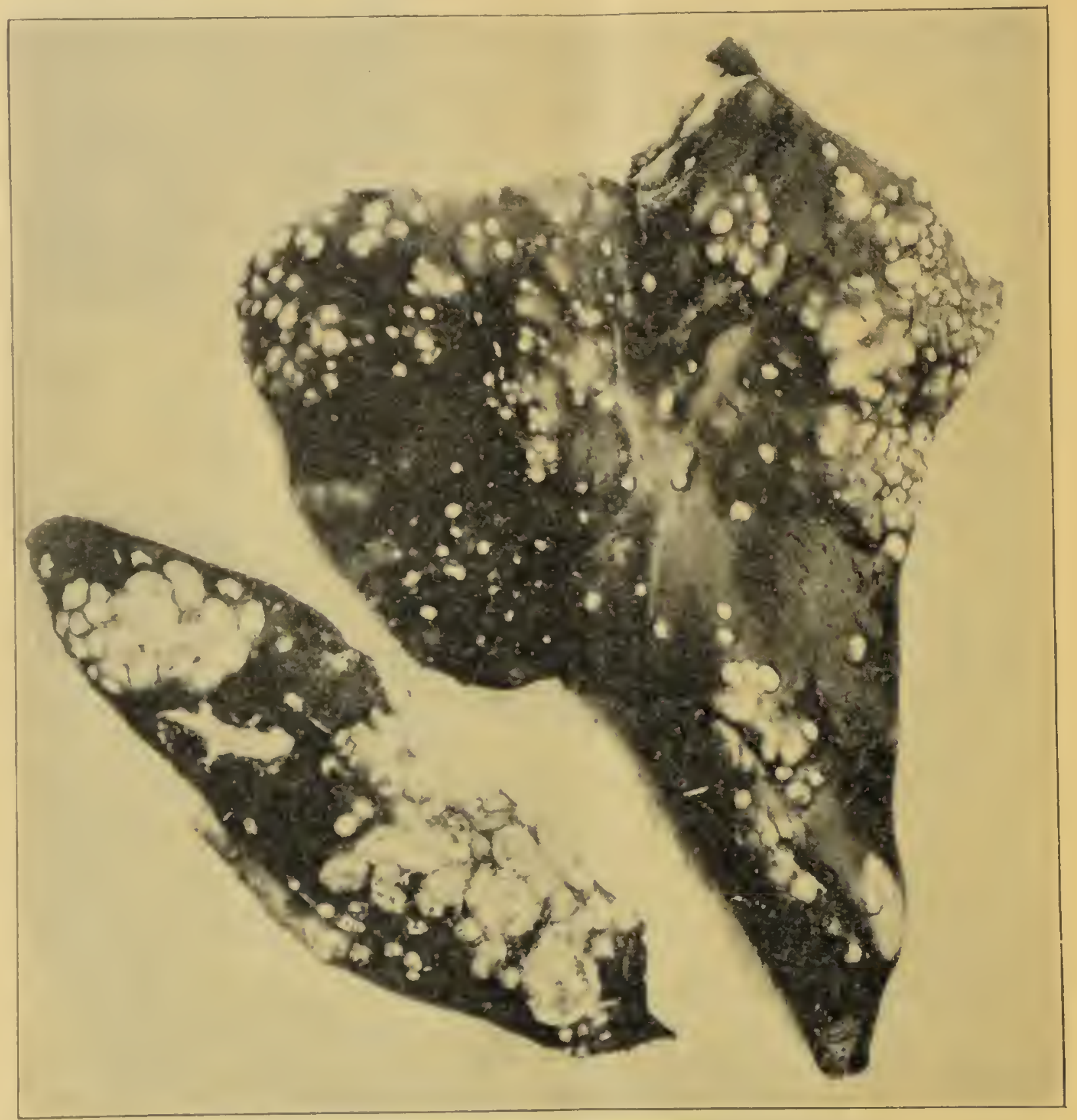

FIG. A- - I irer and spleen shoming extensive lecions of tuherculosis. 


\section{THE TUBERCULIN TEST.}

Testing animals with tuberculin is the process of introducing tuberculin into the animal and interpreting results according to wellknown standards. Tuberculin is a laboratory product prepared scientifically and, when of standard potency and in the hands of skillful persons, it is a reliable agent for detecting tuberculosis in animals. It contains no living tubercle bacilli but is a product of the growth of tubercle bacilli properly mixed with a substance on which it has grown and properly diluted and preserved. No harm can result to healthy animals from the proper application of tuberculin even if doses many times greater than the regular ones are used.

The use of tuberculin by untrained persons is to be discouraged for the reason that in many cases its effect on tuberculous animals is unobserved and not understood by those unfamiliar with its action. Tuberculin, by its immunizing property, can cause tuberculous animals to fail to respond to its application at another time; therefore it may be misused by unscrupulous persons.

\section{THE SUBCUTANEOUS TEST (UNDER THE SKIN).}

The most frequently used method of testing is the subcutaneous test, which consists in injecting the proper quantity of tuberculin underneath the skin into the subcutaneous tissue. If an animal is tuberculous, the action of the tuberculin causes a fever, which is indicated by a rise in temperature. This rise, under ordinary conditions, may occur any time between the eighth and twentieth hours after the tuberculin is injected, but in some cases it is desirable to measure the temperature before the eighth hour and continue to the twenty-fourth hour or longer.

The temperatures are measured at least 3 times in advance of the injection, at 2-hour intervals, to learn whether the animal is in proper condition to receive the test. The temperatures after injection are taken every 2 hours until the test is completed. The proper interpretation of the temperatures is made by the person applying the test, and a careful observance of any clinical changes is always important in determining the result. It can not be set forth too strongly that the test including the two following methods, should be attempted only by those who are properly qualified to do the work.

\section{THE INTRADERMAL TEST (INTO THE SKIN).}

The intradermal test for detecting tuberculosis is used to a considerable extent, especially on range cattle not easily controlled. When made by those who have become skilled in its application, it is very accurate. In this test the tuberculin is injected between the layers of the skin, only a few drops being used, and it is usually 
applied in the region at the base of the tail, where the skin is soft and nearly hairless. The intradermal test is satisfactory also for the diagnosis of tuberculosis in swine and, when so used, the tuberculin is applied into the skin of the ear near its base.

The reaction from the intradermal test consists of a swelling at the point of injection and is obserred from ts to $10 \mathrm{~s}$ hours after the injection. 'The character of the swelling raries, and a proper diagnosis of tuberculosis by this test can be made only by an experienced person.

\section{THE OPHTHALMIC TEST (INTO THE EYE).}

Still another method, known as the ophthalmic, is used to some extent and has been found to be of considerable value in what is known as "check" testing; that is, it is used in connection with either of the preriously described methods. Sometimes a tuberculous animal that fails to react to those tests shows evidence of the

RELIABILITY OF THE PRINCIPAL TUBERCULIN TESTS.

The subcutaneous test is the principal test used by the U. S. Bureau of Animal Industry. It consists in injecting, under the skin, a small quantity of tuberculin. Carefully and conscientiously applied, witi good judgment exercised in both its administration and interpretation, it is wholly effective.

The intradermal test is recognized by the bureau on strictly range cattle or animals whose movements are difficult to control, and in area work. In this test the tuberculin is injected between the layers of the skin.

The ophthalmic test, or so-called "eye test," is not at present accepted for testing cattle for interstate shipment, though it has value as a check test and is recognized for that purpose. It is applied by placing the ophthalmic tuberculin in one eye, using the other as a check. The ophthalmic test has given best results under farm conditions or in other cases where the eyes are normal. For testing cattle in transit or in the stockyard the test is less dependable, owing to the fact that the eyes may be abnormal as the result of irritation or injury from dust, cinders, or other results of transit. In all cases the tests, used either alone or in combination, should be applied by capable persons familiar with tuberculin testing. 


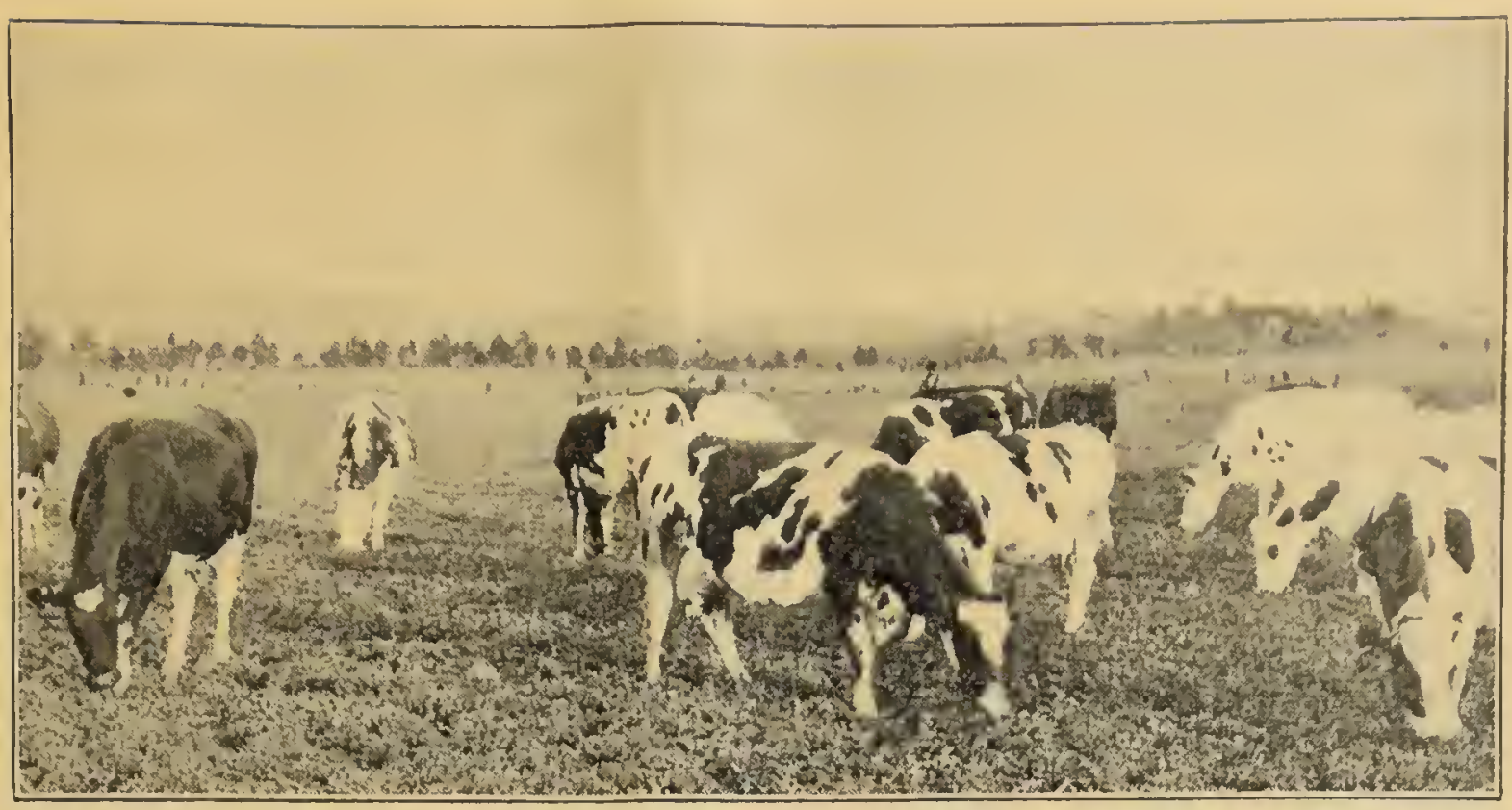

FIG. 9.-Part of a herd of 69 cattle, 30 per cent tuberculous in 1917, 5 per cent tuberculous in 1918,100 per cent free from tuberculosis in 1919. The herd is now accredited.

disease upon the application of the ophthalmic test. The oplithalmic tubcrculin is placed in one eye and the other eye is used as a check. A reaction is indicated by a characteristic discharge from

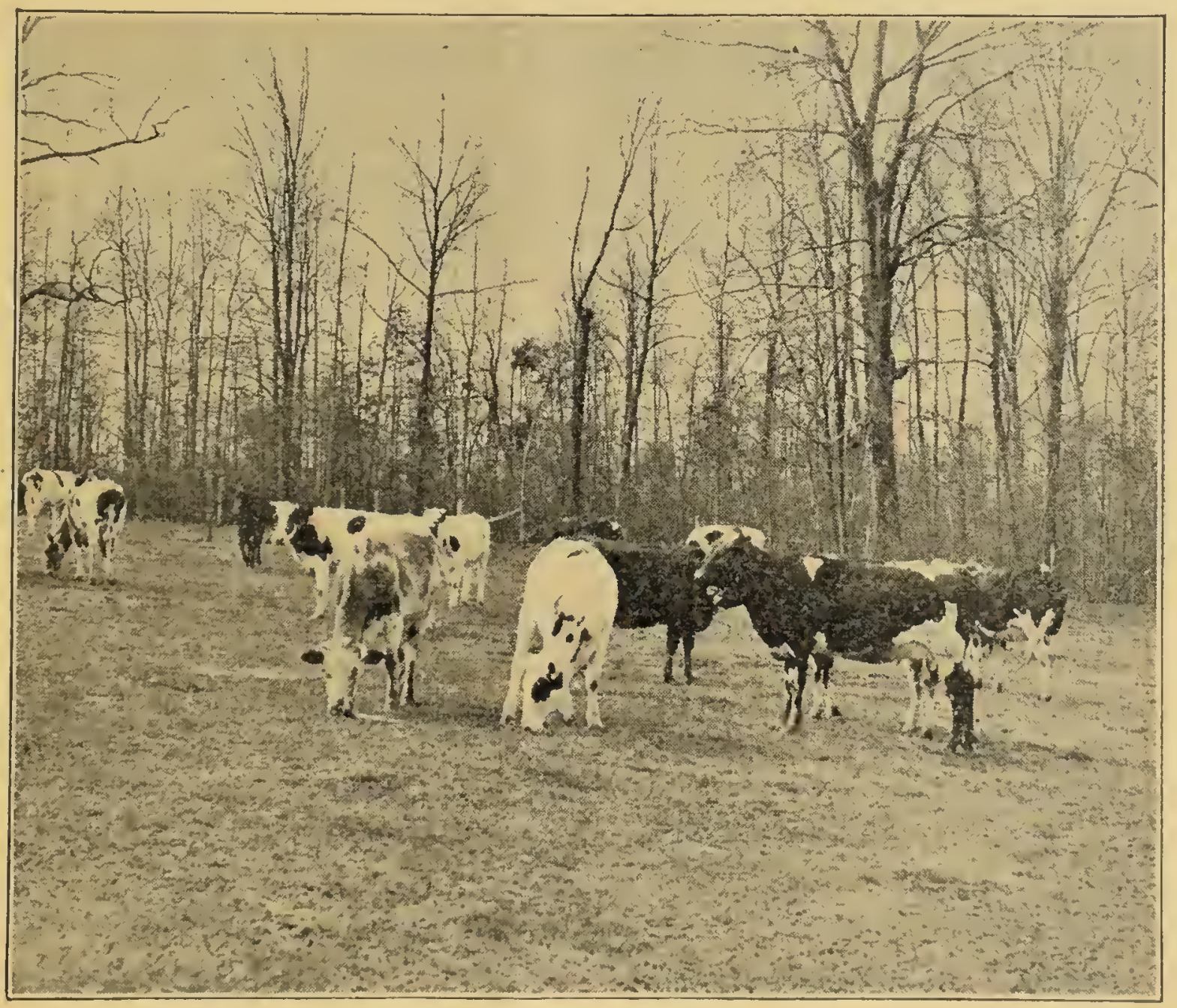

FIG. 10.-How a herd may become reinfected with tuberculosis. This herd was free from tuberculosis for a number of years. During 1917, 4 cattle were purchased in another State and placed in the herd without proper tuberculin test. When official test was made, December, 1917, 5 reactors were found. Three of the reactors were slaughtered and $2 \mathrm{kept}$ in the herd. At the next test, January, 1919,11 reactors and 2 suspects were in the herd of 28 cattle. 
the cye receiring the treatment, which may occur in from 3 to 10 hours after the application or eren later. Some swelling and inflammation of the ere and lids are often noted.

\section{POST-MORTEM APPEARANCES.}

Animals affected with tuberculosis may show the effects of the discase in almost any-part of the body. In adranced cases the lesions are easily found, but when the disease is of recent origin or if a slightly diseased area has been encapsulated or closed up, it is often rery difficult to find evidence of the disease. Lesions in adranced cases generally appear as nodules or lumps, which are tubercles formed as a result of the discase. These lumps may be found in great numbers in the lungs and abdominal organs. The lesions are of rarious sizes and may contain pus, either soft or hard; many times it is gritty. Tubercles are often found in rarious numbers attached to the walls of the thoracic and abdominal eavities. Lesions of the disease also occur in the lungs, liver, and spleen. 'The lympl glands, to some extent, are usually affected, and, when cut into, show diseased areas characteristic of tuberculosis.

Lesions of the disease may be found also in the skin and in or on the bones. In animals only slightly diseased, the lesion may be hidden so that it is impossible for eren the most skillful person in post-mortem work to find it. A microseopic examination of the lymphatic glands or other tissues of ten rereals the presence of tubercle bacilli when no lesions can be seen by the naked eye, a condition showing that the disease is just starting. When animals hare reacted to the tuberculin test, a very careful post-mortem examination should be made. The action of tuberculin is often discredited when on post-mortem the lesions are not plainly seen, but experience of many years has shown that rery few animals reacting to the test were not affected with tuberculosis to some extent even though some were very sight.

\section{METHODS OF ERADICATION.}

Cattle owners who do not know whether tuberculosis exists among their animals should ascertain the fact by having them tuberculintested and physically examined by a qualified reterinarian. In many cases thousands of dollars and rery raluable breeding animals might have been saved by taking up tuberculosis-eradication work in time. Three main projects comprise the general campaign of eradication, as follows:

1. Eradication of tuberculosis from pure-bred herds of cattle.

2. Eradication of tubereulosis from circumscribed areas.

3. Eradication of tuberculosis from swine. 
It is important to eradicate tuberculosis from pure-bred herds of cattle at the earliest possible date because the spread of the disease is greater among such animals than among grade cattle. 'The reason is plain; pure-bred animals are shipped extensively to every part of the United States for breeding purposes. A pure-bred bull or cow may be shipped from Maine to 'Texas, or from the State of Washington to Florida. If it is diseased and is introduced into a healthy herd, it not only fails to fulfill the purpose for which it was intendedthe upbreeding of the herd-but it actually causes heavy damage by spreading the disease to liealthy animals.

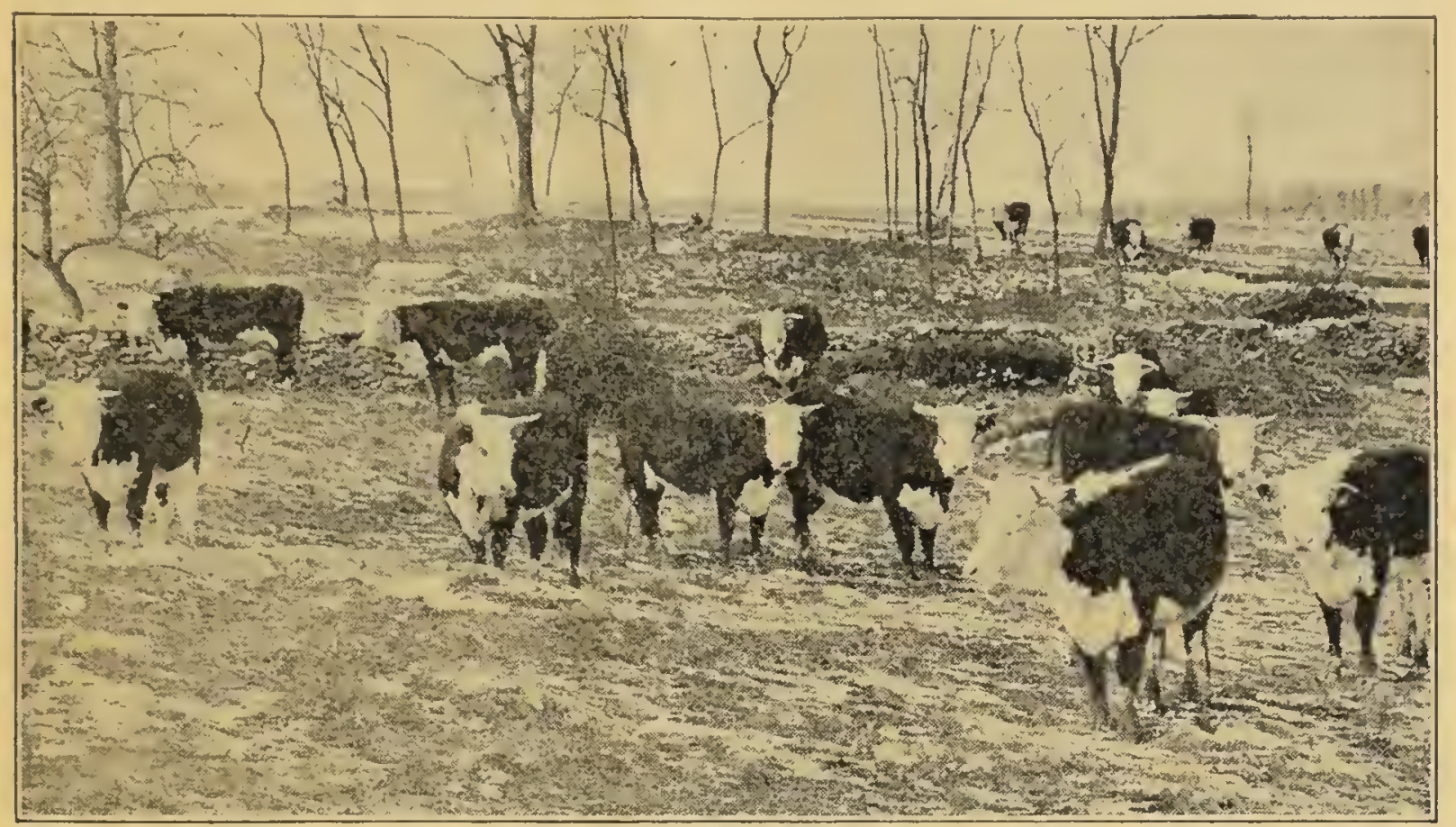

FxG. 11. This IIereford herd was freed from tuberculosis within 3 years. The first test, in 1916, showed the herd to be 10 per cent tuberculous. The reactors were removed and in 1918 all the 62 animals in the berd were found to be healthy.

\section{ACCREDITED-HERD OR HONOR-ROLL PLAN.}

The breeders of pure-bred registered cattle fully appreciated the above-mentioned fact when, together with the live-stock sanitary officials of practically all the States, they adopted what is known as the accredited-herd plan, the principles of which are that herds found to be free from tuberculosis on two successive annual tests are placed on the Honor Roll, and a certificate is given to the owner by the State and the Federal Government. The certificate entitles animals of that herd to be shipped interstate without further tuberculin testing for a period of one year. This plan is becoming well known to breeders throughout the United States. The progress of the accredited-herd plan is given in Table 2 .

The methods of eradicating tuberculosis from grade herds are, of course, the same as for pure breds. No owner can rest assured that his herd is free from tuberculosis unless it has been properly 
tuberculin tested. To make a satisfactory test all the cattle should be in normal condition and, so far as practicable, the cattle should be stabled under usual conditions and among usual surroundings. Feeding and watering should be conducted in the customary manner, with the exception that feed and water should be giren only after the temperature has been taken. Careful physical cxamination of each animal should be made before or during the application of the test. If animals react to the test ther must be separated from the rest of the herd.

TAmt. :-.-Status of cooperative tubcrculosis-cradication urork, including all herds wnder superition, Amil 1, 191?.

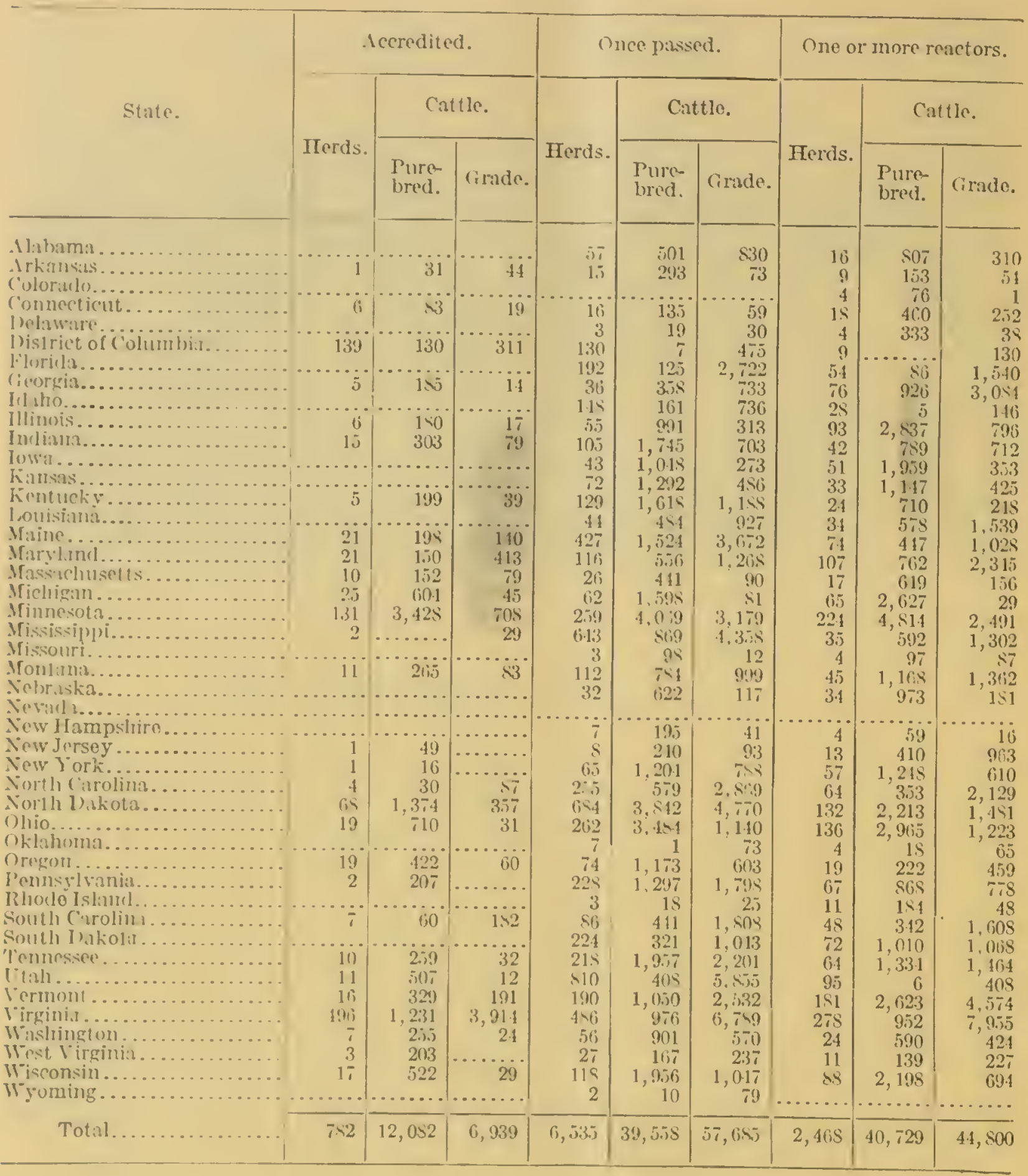




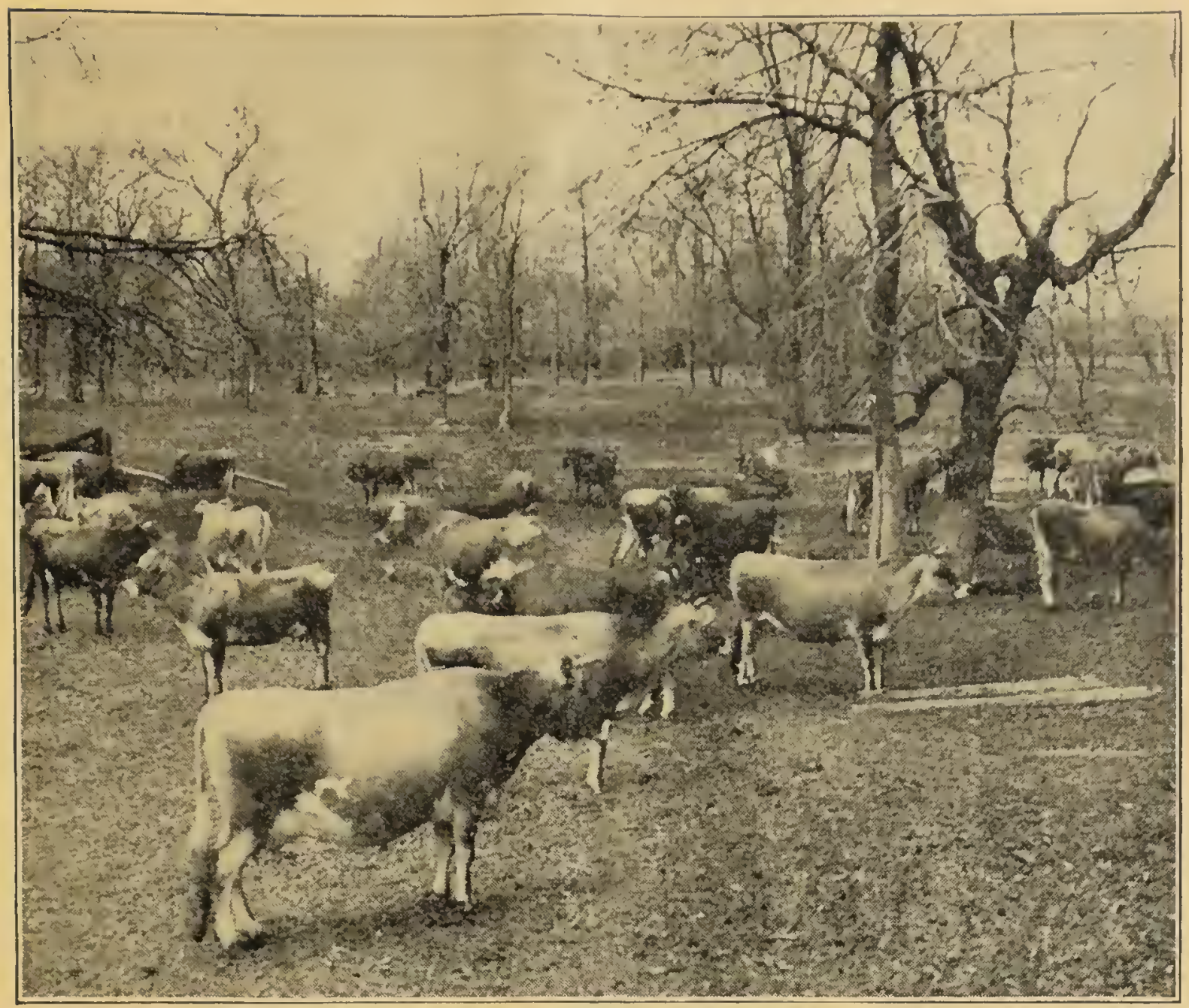

FIG. 12.- $\mathrm{An}$ accredited Jersey herd, Minnesota.

PRINCIPAL BENEFITS OF COMPLETE ERADICATION OF TUBERCULOSIS.

Increased value of individual animal and increased herd value.

Ability to ship interstate from accredited herds without further testing for a period of one year.

The owner's name being listed in pamphlets published by the respective States and the Bureau of Animal Industry.

Confidence by those who desire to purchase cattle to add to their herds.

Satisfaction of knowing that the dairy products offered for sale are free from diseased germs.

Elimination of economic losses caused by the disease. 


\section{ERADICATION FROM AREAS.}

The unit territory to be worked will depend mainly upon the extent to which the disease has spread. In some States practically every county contains numerous tuberculous herds, so that, to control the disease effectively, all the herds must be tuber'ulin tested. In other States, however, the disease is confined to the beef and dairy herds recently established or to which new animals have lately been added. In the latter case it would not be necessary to test all the cattle, but the examination of the herds should be sufficient to demonstrate most satisfactorily that no diseased herds are overlooked. This can be done by testing several herds in each section of the count $y$ wherever there is a suspicion that the discase may exist.

As a general plan, it is best to take up the work by counties, and substantial cooperation should be obtained from the county government. Each county should pay (1) part of the expense of extcrminating the disease by employing inspectors to make the tests, (2) part of the indemnities paid for tuberculous animals, and (3) its share of the cost of cleaning and disinfecting infected barms, stables, and sheds. When a large percentage of the herds of a county are diseased, it is advisable to (lean up the herds within a township or possibly onethird or one-half of the area. The progress depends upon the degree of infection found and the cooperation furnished by the owners.

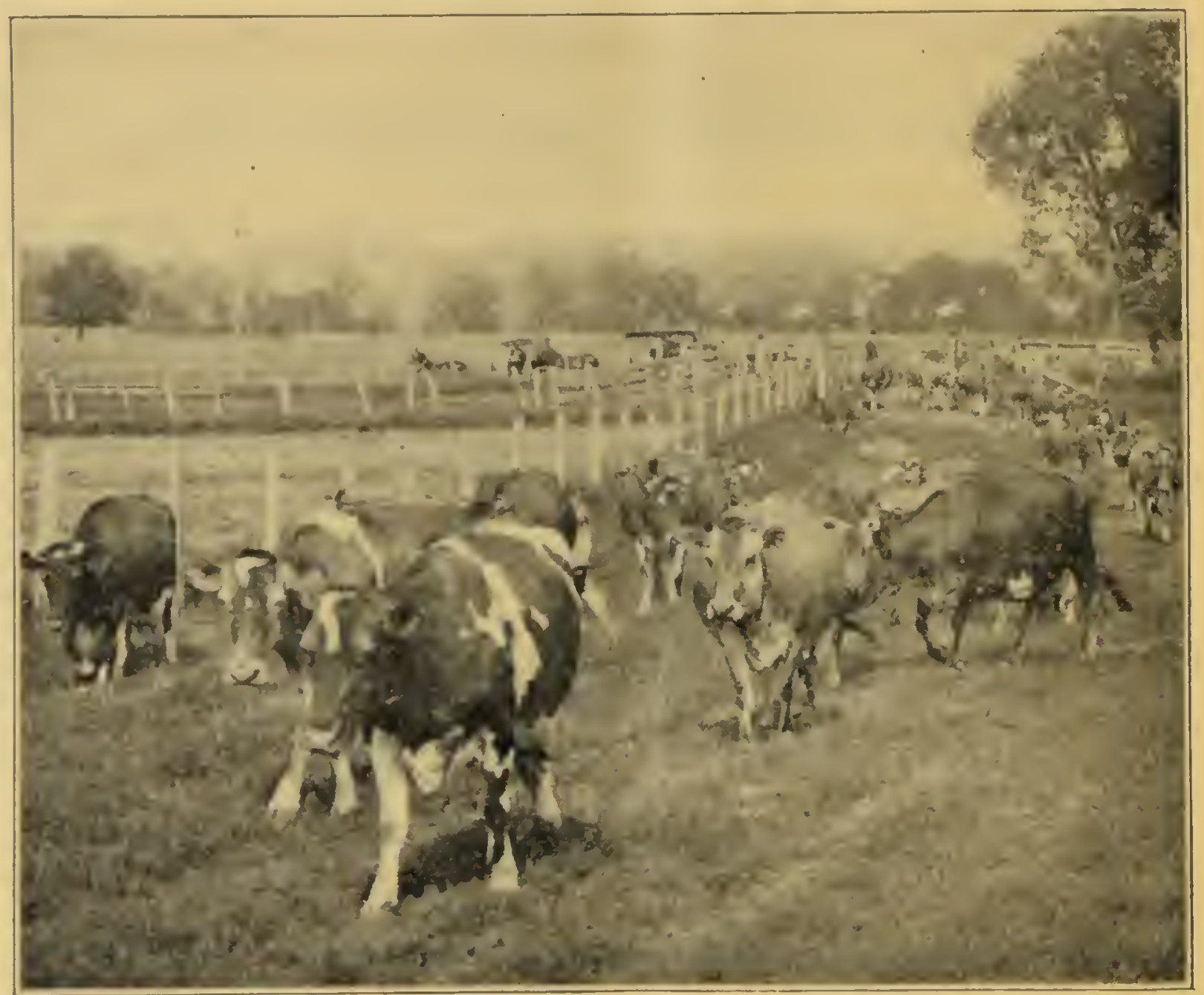

FIG. 13. - An accredited fuernsey herd, Wisconsin. 


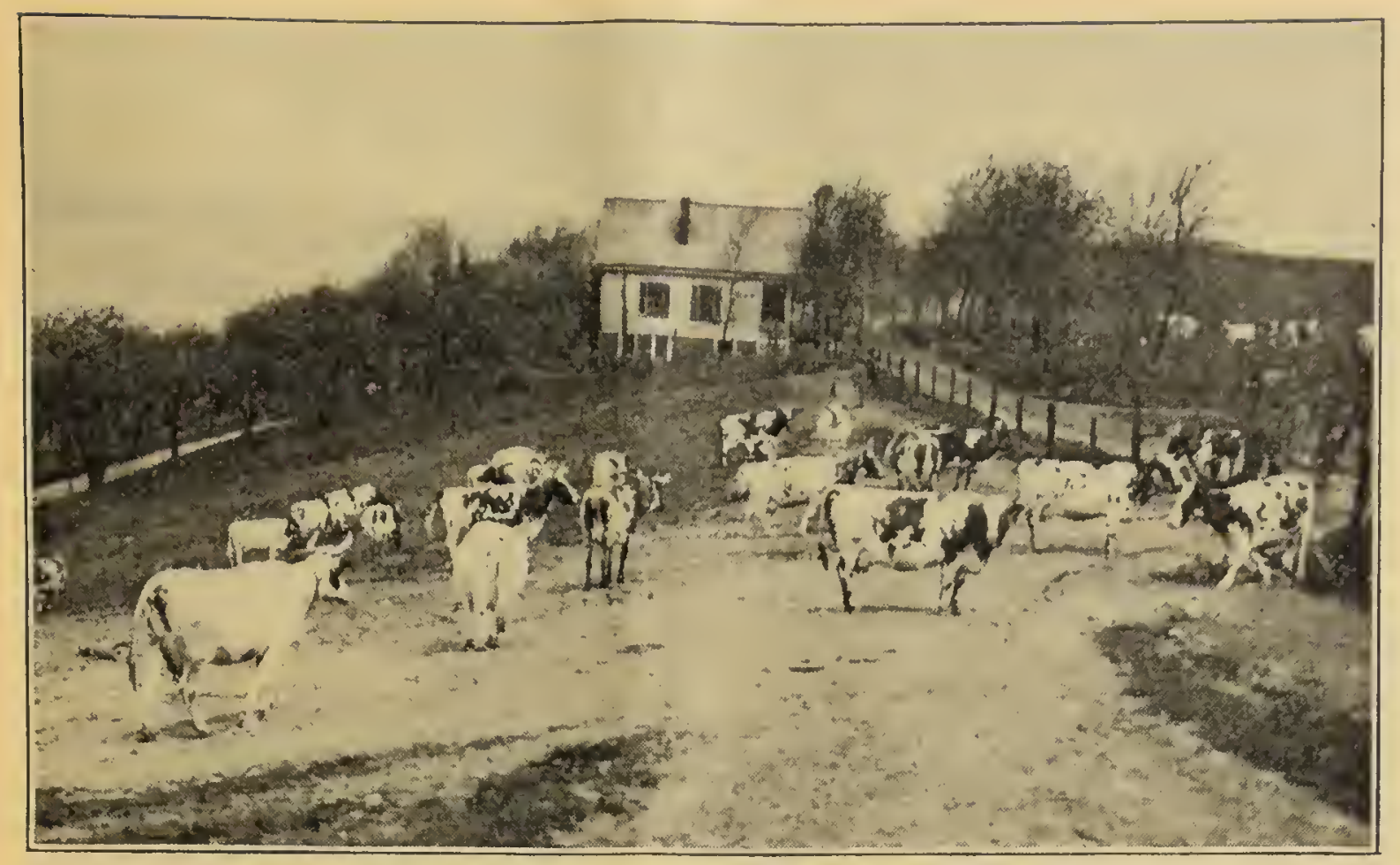

FIG. 14. $-\Lambda$ accredited $\Lambda$ yrshire herd, West Virginia.

In 1910 the Bureau of Animal Industry took up the eradication of tuberculosis from the herds in the District of Columbia, which has an area of 60 square miles. At that time 1,701 cattle were found. Every animal was tuberculin tested; of the total number, 321 cattle, or 18.87 per cent, were tuberculous. The reactors were removed from the herds and, in most instances, were slaughtered. The infected barns, sheds, and premises were cleaned and disinfected.

Each year since the inauguration of the campaign all the cattle have been tuberculin tested with the result that the infection has almost disappeared.

There are States in which tuberculosis exists to less than 1 per cent among all the bovine population. The plan of carrying on eradication in several counties at the same time in those States is practicable and is being conducted in a number of States.

Before undertaking the work in any area, large or small, the cattle owners should be consulted, and unless they are willing to lend their earnest cooperation and know the sacrifice they may have to make, it is inadvisable to start. The better the organization and the more nearly perfect the plans are made, the more efficiently the work should progress.

The larger herds, especially around cities and those supplying milk locally and for shipment to other cities, should be tested before the small lots. If it is known that the herds are but slightly infected, the intradermal method should be employed, as faster progress can be made with it than with the subcutaneous test. If reactors are found in using the intradermal test, the entire herd should be tested subcutaneously within a short time. The ophthalmic test may also be used in conjunction with the subcutaneous in "check" testing" 


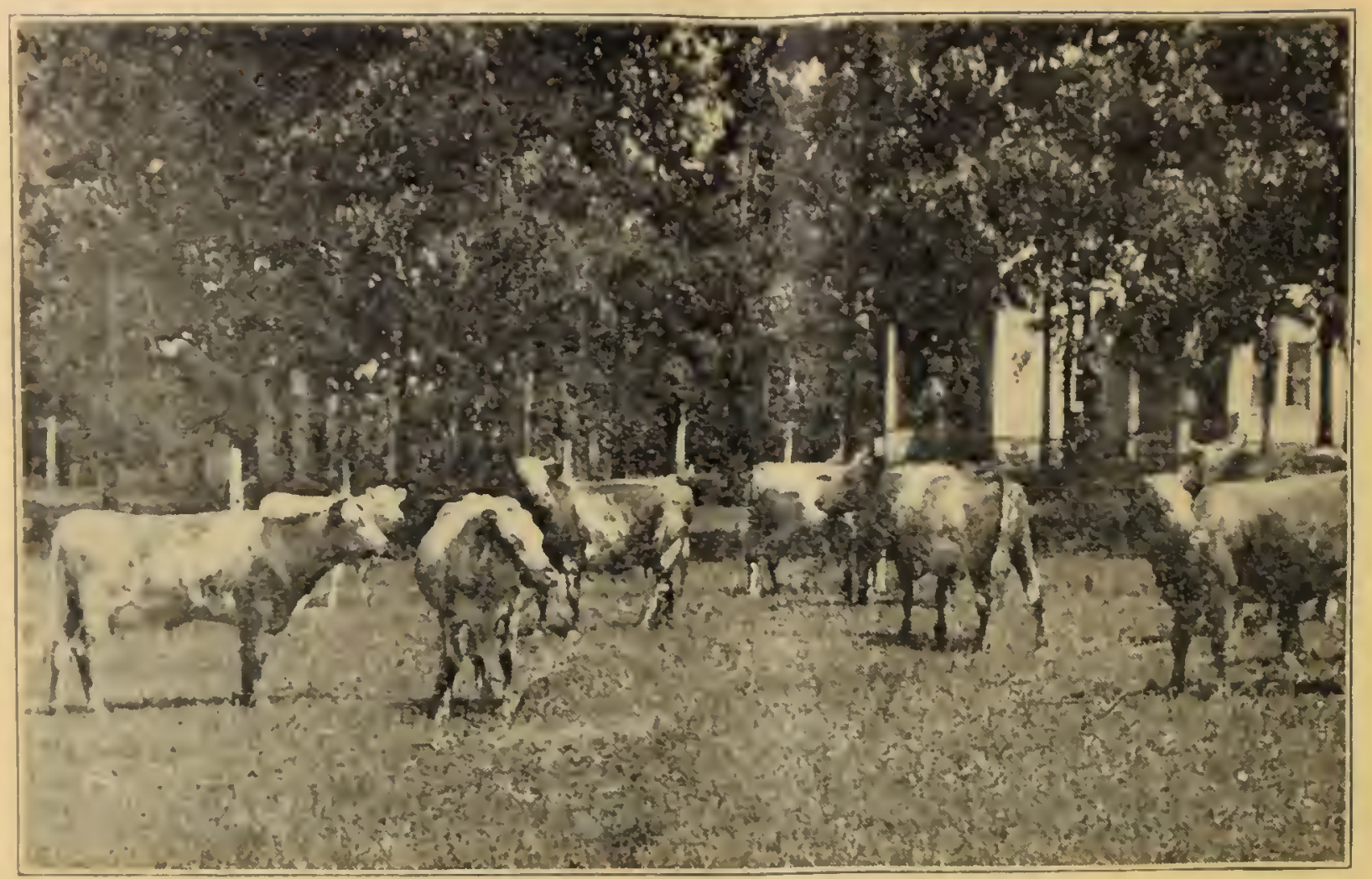

Fir. 1.;.-In accredited herd of puro bred Milking Shortherns, Virginia.

herds. General experience shows that it is sound practice, if there is $a n y$ doubt, to use all three methods of testing with tuberculin. Such a policy is especially applicable to cattle which have been tested frequently, and among herds which are or have been extensively diseasind.

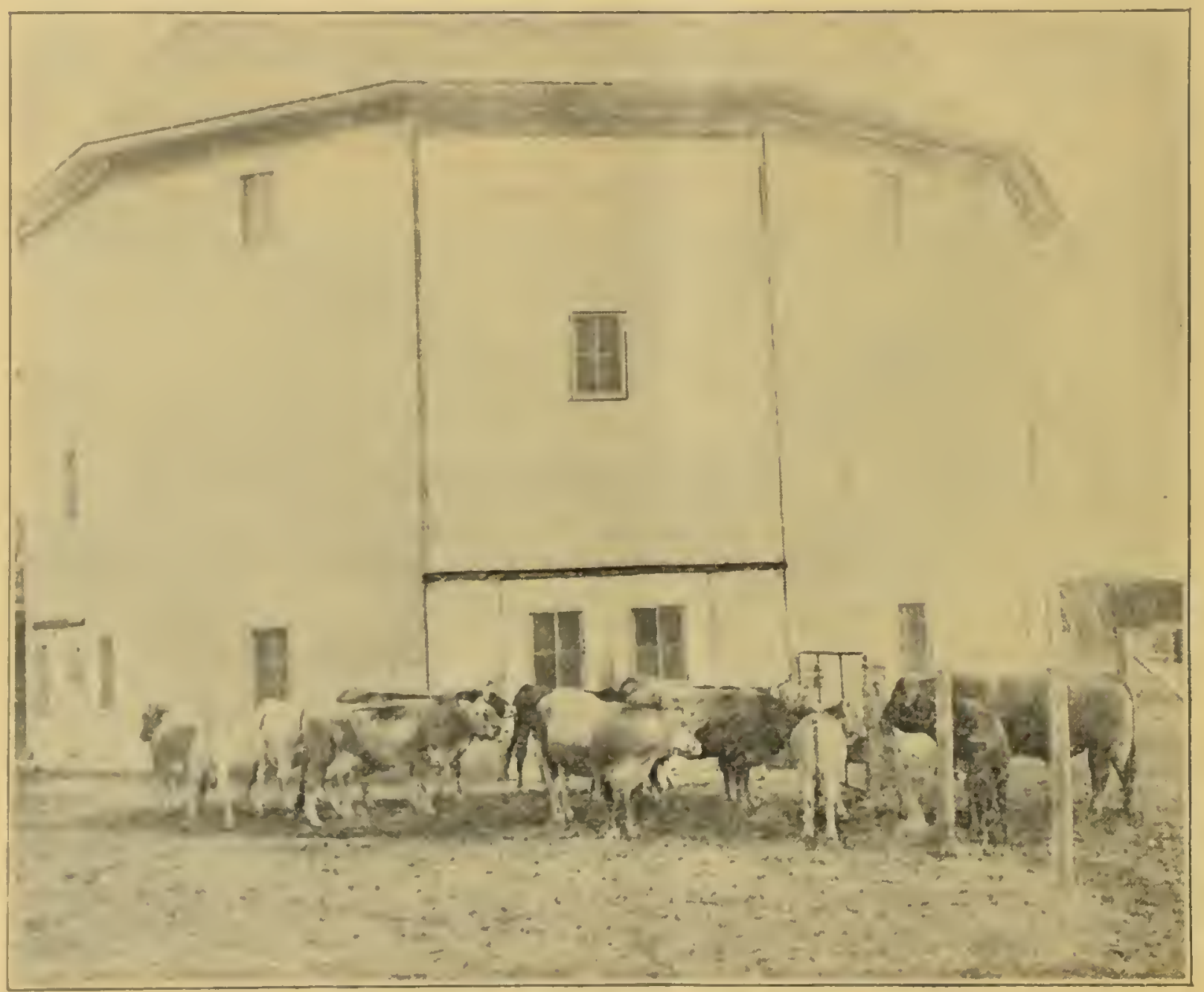

FIG. 16. - An accredited Bromn Sriss herd, Indiana. 


\section{ERADICATION FROM SWINE.}

With the gradual elimination of tuberculosis from cattle, the disease among swine will grow correspondingly smaller. It is not necessary to tuberculin test all the swine herds because, with the exception of valuable breeding animals, it is more economical to slaughter the diseased ones when fat than to undertake to exterminate the discase in any other way.

In the case of suspected, valuable pure-bred swine, their freedom from tuberculosis can be determined definitely by the intradermal method, which is practicable and reliable.

'The injection is near the base of the left ear; the other ear acts as a check for comparison. A reaction is manifested by a swelling in the

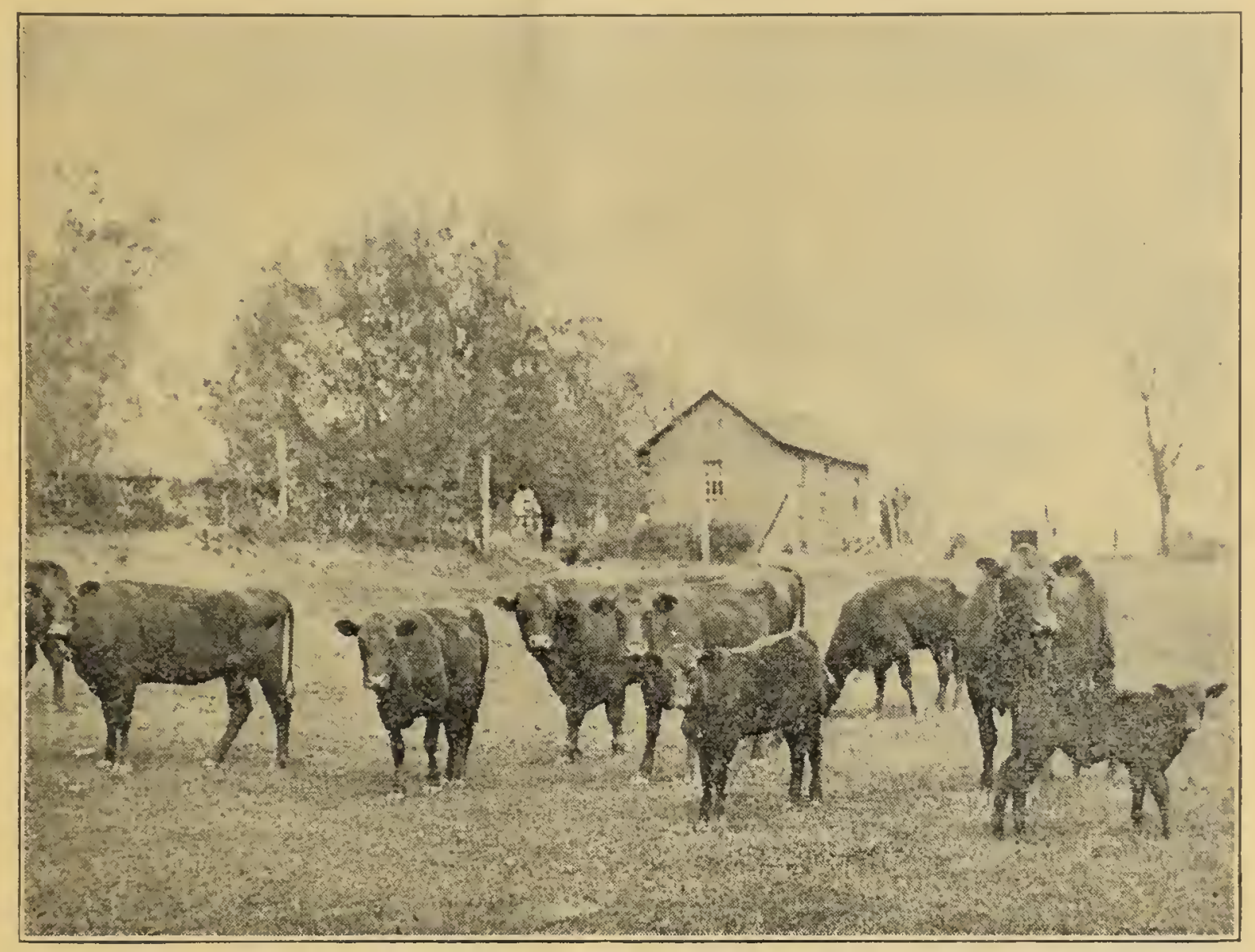

FIG. 17. $-\Lambda$ n accredited Red Poll herd, Virginia.

region where the tuberculin was injected. The swelling may appear any time from the 24 th to the 104th hour after injection and will remain for several days. As in the case of cattle, diseased swine should be removed from the farm, and the sheds, farrowing houses, and the lots should be thoroughly cleaned and disinfected.

\section{MEASURES OF PREVENTION.}

Since, after many years of study and experience, no satisfactory cure for tuberculosis among animals has been found, prevention of the disease is extremely important. State and Federal Governments have made vigorous efforts to stop the spread of the discase by regu- 
lating the morements of cattle, and recently, with that object in riew, action has been taken in some localities to regulate the morement of cattle from one county to another. Regulation of intercounty morement should be encouraged because it brings the matter nearer home to the live-stock owner. It is he who must take a very important part all through the campaign of tuberculosis eradication, and if he is in faror of measures to prevent the spread of the disease and faithfully abides by those measures, cradication will be accomplished more speedily.

From what has been said already about the dangers of shipping diseased cattle, it is plain that the movement of tuberculous cattle, except for immediate slaughter or to quarantine, must be stopped

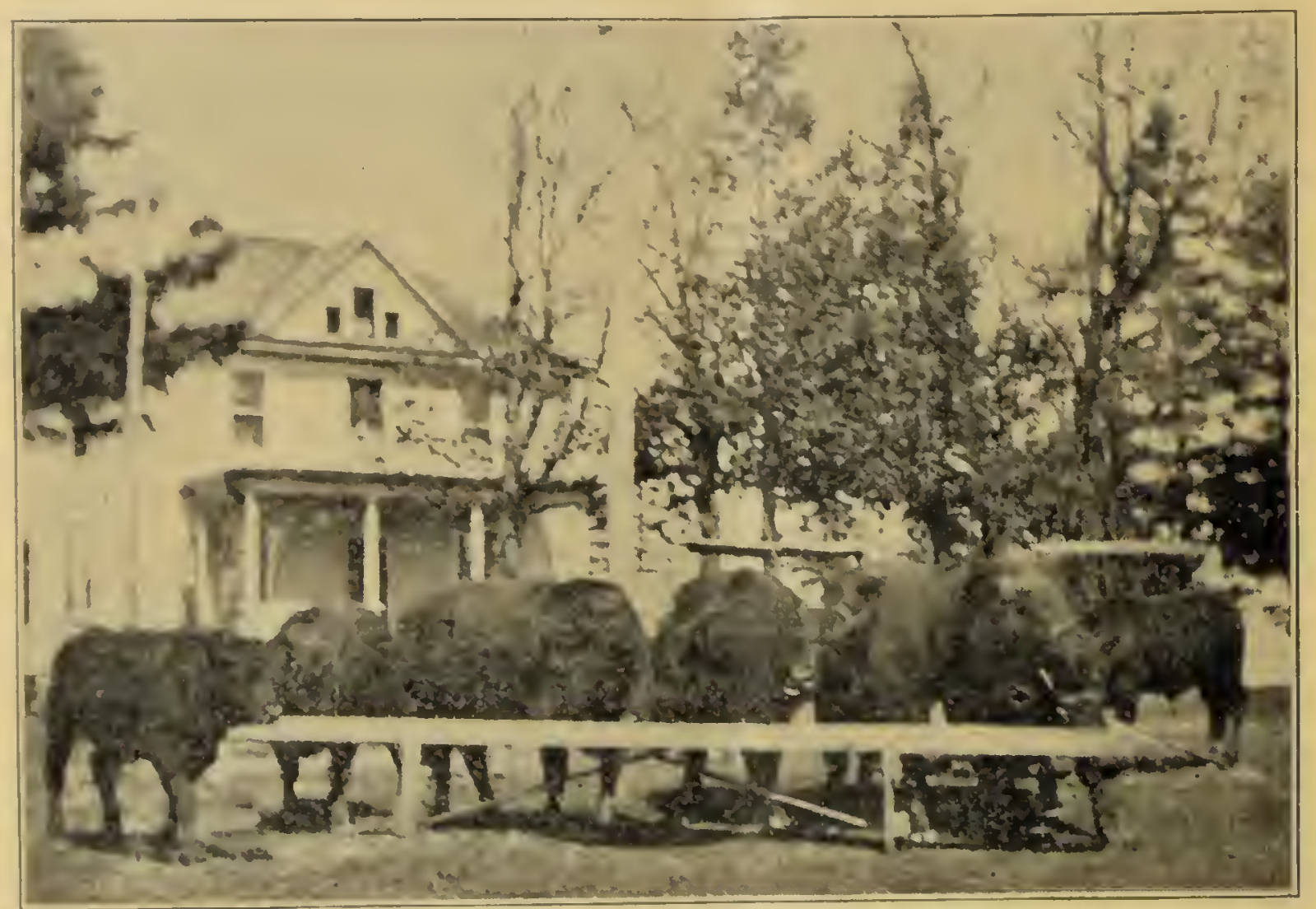

Fic. 15.-An aceredited $\Lambda$ herdeen-Ingus herd, Minmesota.

whenever possible. After diseased animals are found and remored from the premises, a very thorough cleaning and washing of the inside of the barn and other buildings where the animals have becn should be made. This must be followed by the proper application of some approved disinfectant. The use of disinfectants without first doing the necessary and proper cleaning is ineffective for the reason that the germs of the discase must be cxposed. All utensils or anything else that may have become contaminated by use around the diseased animals should likewise be cheaned and disinfected. 'The manure and refuse must be hauled from barnyards or lots to plowed fields, spread thin, and exposed to the sunlight. The yards and lots, including feed troughs, water troughs, and fences can then be sprayed properly with the disinfectant. 


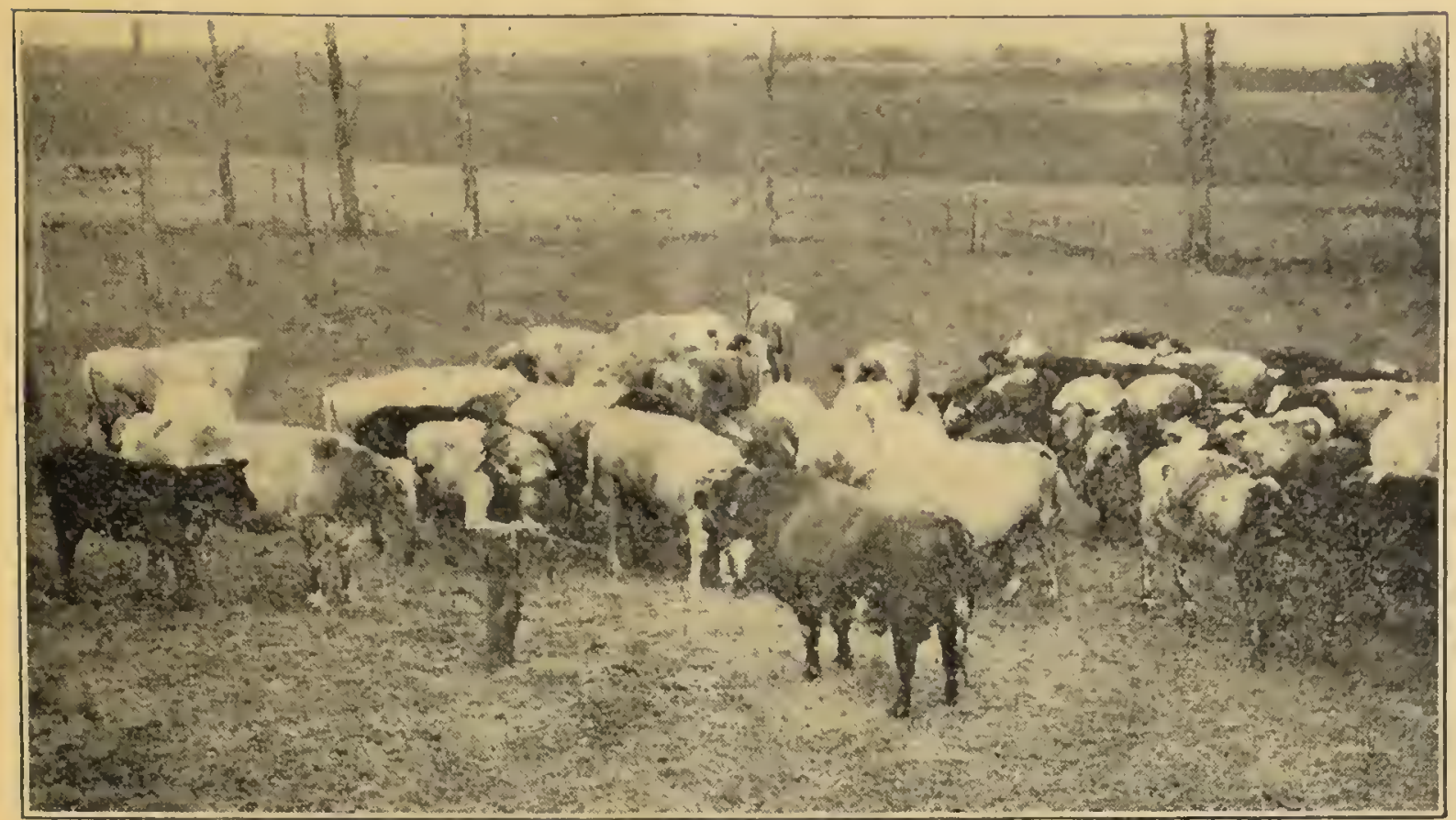

FTG. 19. - An accredited Shorthorn herd, North Dakota.

All this means much work but it must be done to prevent infection from spreading to the healthy animals. Proper sanitary. conditions on premises where live stock are kept is of great importance in keeping the animals healthy and able to resist disease. Sanitation, in its broad sense, includes the admission of abundant sunlight and fresh air properly regulated.

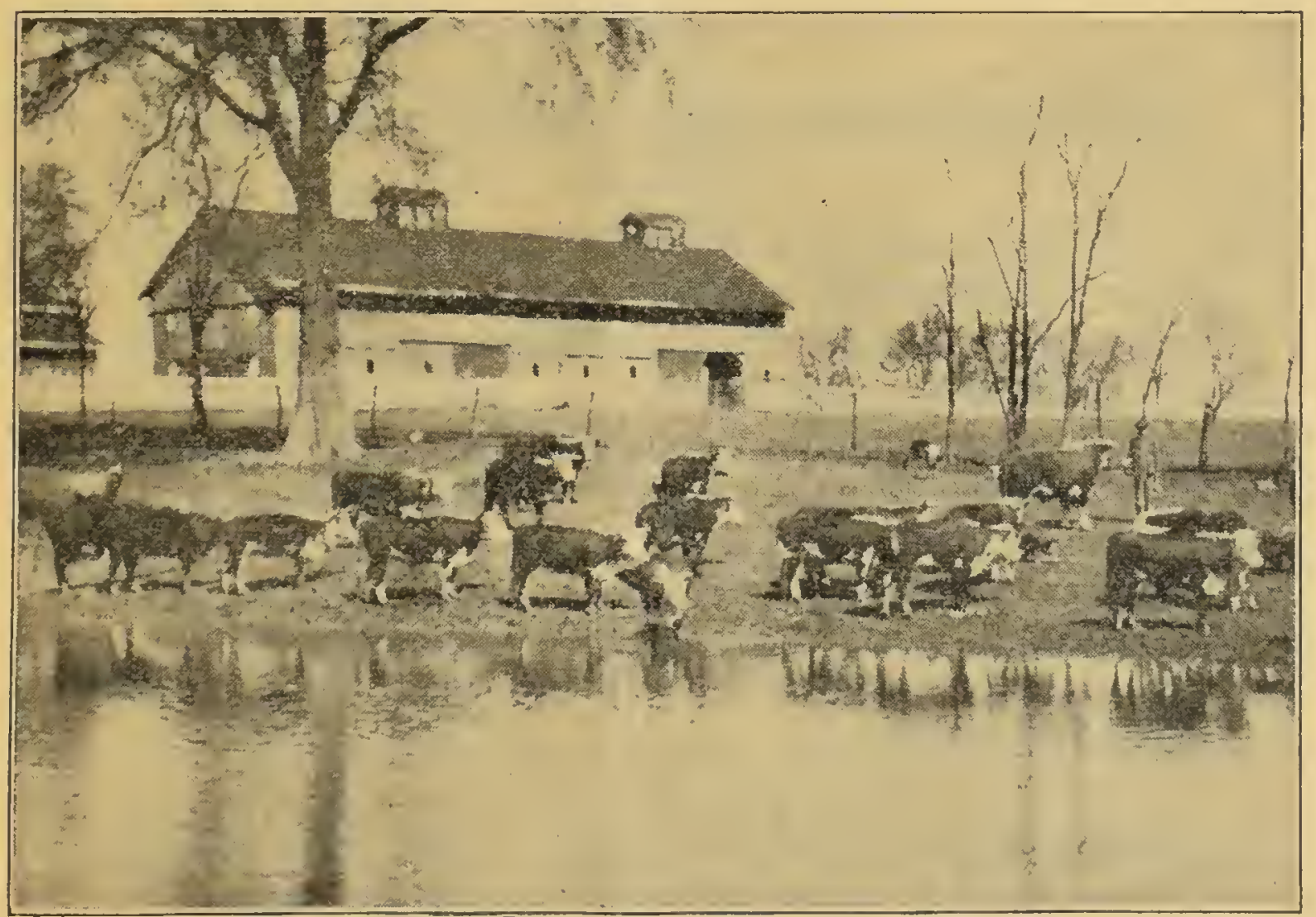

Fig. 20.-An accredited Hereford herd, Kentucky. 


\section{DISPOSAL OF REACTORS.}

The disposal of reactors depends larely upon the State laws and live-stock regulations of the State in which the herd belongs. If the animals are pure bred and registered and of unusual merit, they should be segregated, preferably on farms set aside by the State or by the pure-bred cattle associations, for the purpose of retaining tuberculous cattle in quarantine. If the condemned animals are

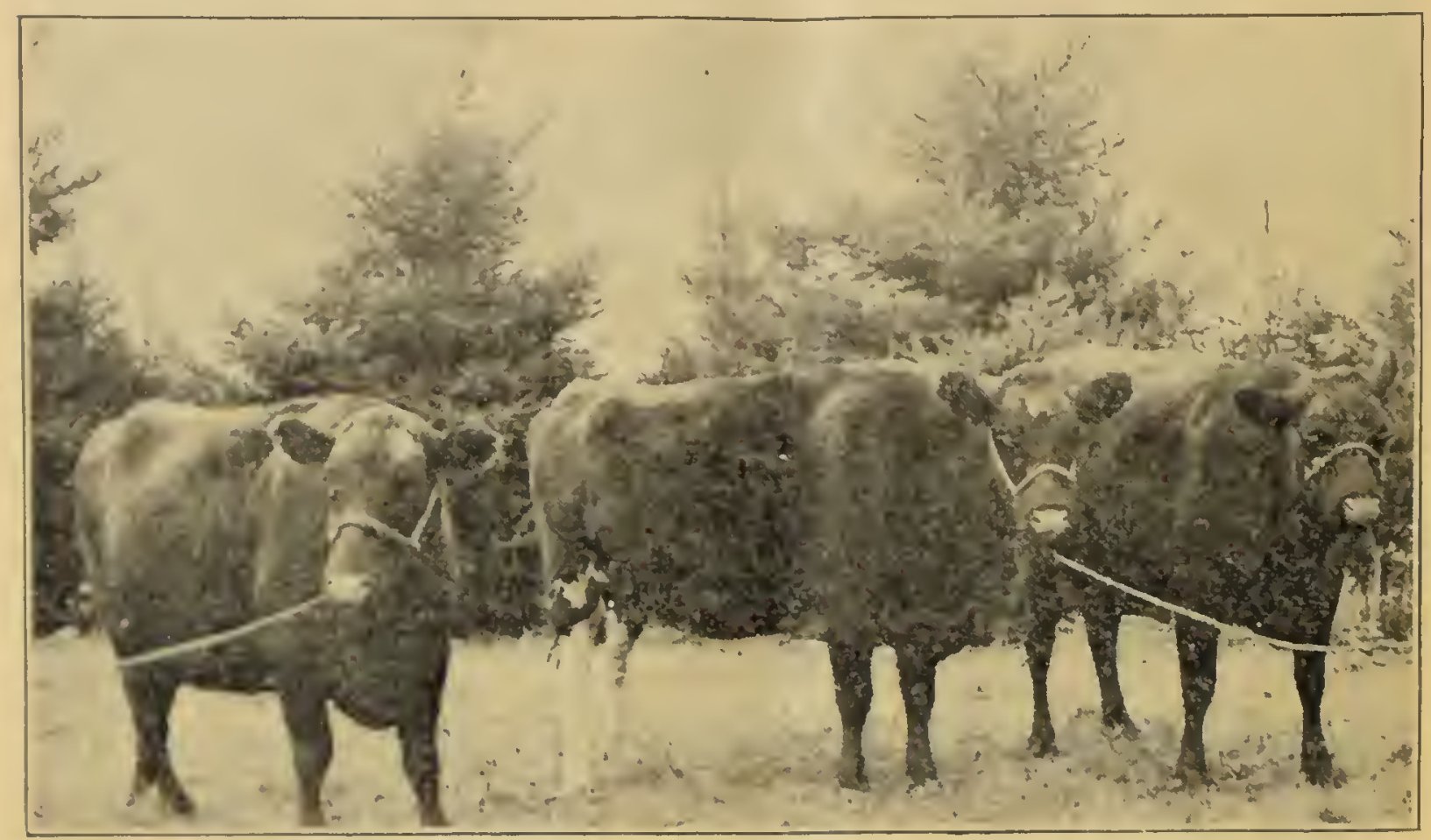

Firs. 21.-An accredited Polled Durham herd, Mrimnesota.

\section{THE ACCREDITED-HERD PLAN-EVERY CATTLE OWNER EIIGIBLE.}

A tuberculosis-free accredited herd is one which has been tuberculin tested by the subcutaneous method or any other approved method under the supervision of the Bureau of Animal Industry, or of a regularly employed veterinary inspector of the State in which cooperative tuberculosis eradication is being conducted.

It is a herd in which no animal affected with tuberculosis has been found upon two annual or three semiannual tests, made as described, and by physical examination.

Owners of tuberculosis-iree herds receive a certificate issued by the bureall and the State livestock sanitary authorities. The certificate is good for one year from the date of the test, unless revoked at an earlier date. 
grade cattle, or pure breds not specially valuable for breeding, it will probably be more economical to have them slaughtered than to hold them in quarantine. Of course the fact is recognized that in States and communities where tuberculosis exists extensively the slaughtering of all reactors is impracticable. In such instances the infection can be reduced on all the farms by keeping the tuberculous animals separate from the healthy ones. The tuberculous cattle are kept under quarantine restrictions until no longer profitable; meanwhile the healthy animals are safe from the danger of infection.

\section{RETESTING.}

It is rather uncommon for tuberculosis to be eradicated from an infected herd after one tubcrculin test. After the removal of reactors the herd should be retested at the expiration of six months, and a second retest may be advisable six months Iater, but the practice of testing herds more frequently than that is not usually advised. After two or three semiannual tests the herd should not be tested of tener than every 12 months. While the subcutaneous test is considered preferable for gentle cattle, the ophthalmic and intradermal methods of testing may be employed to advantage as adjuncts to it; and it is believed that in some instances herds may be freed of tuberculosis earlier by the judicious use of all three methods. No gencral outline can be given as to when all three tests should be employed; the matter should be left to the judgment of the veterinarian under whose direction the work is carried on.

\section{MARKING ANIMALS FOR IDENTIFICATION.}

It is very important to mark properly all cattle which react to the tuberculin test, so that they may be easily identified as affected with tuberculosis. One method that is quite generally used is that of branding; a letter "T" about 2 inches high is branded on the lower jaw, or sometimes it is placed on other parts of the body where it can be seen readily. In addition to the branding it is advisable to tag the reacting animals so that one may be identified from another, and in that way the results of the post-mortem examination can be connected up with the reporting of the tuberculin tests. The tag is usually placed in the ear of the animal and contains a serial number as well as the word "Reactor."

Another method that is sometimes used is the punching of a letter "T" out of the ear, and it has been quite satisfactory.

The marking of cattle that have passed the tuberculin test is a matter that is being handled in different ways throughout the United States, and it is believed that the present methods of marking will be improved. In some cases a metal ear tag is used and in others certain marks of identification are tattooed in the ear. Tattooizes 
has an advantage over the tagging in that it is less expensive and probably more permanent.

It is not often necessary to require special marks on pure-bred registered cattle, as the owner usually has a method of identification, and this method of marking can be used in connection with the tuberculin test as a record; but on grade animals it is desirable to use some system of marking that will show that the cattle have been tested and found apparently free from tuberulosis.

A system of marking swine so that the origin of those found to be tuberculous on post-mortem examination can be learned would be rery desirable, and some experimental work along this line is now being conducted by the bureau in cooperation with owners and packers. The results so far obtained indicate that the tattooing of a number or some mark of identification into the skin of the hog is the most practicable method but of course it entails additional labor and expense which would amount to a great doal if carried on throughout the country. It is hoped a more practicable and economical means of marking swine for identification will be developed in the future, as much good in the campaign for the eradication of tuberculosis in live stork can be accomplished in that way.

Many shipments which contain tuberculous swine are traced back to the farm by a system of reports kept by the Burcau of Animal Industry. By developing the methods of tracing tubereulous cattle and swine from the abattoir back to the farm where they were raised, efforts can be directed in eradieating the discase from these herds.

\section{APPRAISEMENT AND INDEMNITY.}

In addition to the various benefits derived from eradicating tuberculosis, provision for the appraisement of discased cattle with indemnity for those slaughtered is a further incentive. Federal legislation and supplementary laws in numerous States now divide the burden

WHY THE TUBERCULIN TEST IS HARMLESS.

Tuberculin contains only the sterilized products of the tubercle bacilli. It does not contain any living germ; therefore it is harmless to any animal whether healthy or diseased.

Only diseased animals give typical reactions to the test. The test does not injure animals in a condition of advanced pregnancy, and will not cause them to react if they are free from disease.

Likewise, it does not produce reactions in diseasefree animals which have recently calved. 


\section{HOW THE WORK OF ERADICATION IS DIVIDED BETWEEN STATE AND GOVERNMENT OFFICIALS AND OTHERS.}

Tuberculosis eradication is a cooperative work of the Bureau of Animal Industry of the U. S. Department of Agriculture, the live-stock sanitary offlials of the various States, and individual cattle owners. The bureau and the State officials send veterinary inspectors to apply tuberculin tests to the herds of those owners who sign a cooperative agreement, which places their herds jointly under supervision for the control and eradication of the disease.

of loss, so that the Government, the State, and the owner of the cattle all bear a share of it. Briefly, the Federal law provides that the Secretary of Agriculture may reimburse partly owners of animals destroyed on account of tuberculosis in cooperation with States, counties, and municipalities. The bases upon which Federal indemnities are paid are:

1. No payment shall exceed one-third of the difference between the appraised value of such animal and the salvage value.

2. No payment shall exceed the amount paid or to be paid by the State, county, or municipality.

3. In no case shall any payment be more than $\$ 25$ for any grade animal or more than $\$ 50$ for any pure-bred animal.

4. No payment shall be made unless the owner has complied with all lawful quarantine regulations.

Legislation regarding indemnities for tuberculous cattle varies somewhat in different States and, for detailed and current information on the subject, the reader is referred to his State live-stock sanitary officials or to the inspector in charge representing the Bureau of Animal Industry in cooperative tuberculosis-eradication work. The names and addresses of these officials may be obtained by addressing the Bureau of Animal Industry, U. S. Department of Agriculture.

A careful study of figures 4, 6, 7, and 8 in this bulletin will enable the reader to become familiar with the appearance of the parts of the body most commonly affected. He will also see, even more clearly than can be described, that a real danger exists in permitting diseased animals or those of doubtful health to mingle with others. The illustrations of the accredited herds, on the other hand, sliow the splendid types of cattle which their owners hare subjected to the tuberculin test and which have passed it successfully. 
